\title{
Combined Quantum Mechanical and Electrochemical Study of New Isatin Derivative as Corrosion Inhibitor for Carbon Steel in $3.5 \% \mathrm{NaCl}$
}

\author{
Rehab Majed Kubba ${ }^{1}$, Dhuha Abdul-Kareem Challoob ${ }^{2}$, Suaad Mohammed Hussen ${ }^{3}$ \\ ${ }^{1,2,3}$ Department of Chemistry, College of Science, University of Baghdad, Baghdad, Iraq
}

\begin{abstract}
The inhibiting efficiency of synthesis a new derivative of 5-bromo isatin it is $N$-[(hexahydrodiazepine -3,7-dione-1-yl) aceto]3- (tolylimino)-5-bromo-2-oxo-indole] (5BID) towards carbon steel corrosion have been investigated in three media (vacuum, DMSO, and $\left.\mathrm{H}_{2} \mathrm{O}\right)$ using PM3 and DFT quantum mechanical calculations of (B3LYP) with a 6-311++G (2d, 2p) by using Gaussian-09 program. The calculated physical properties and quantum chemical parameters correlated to the inhibition efficiency all are studied and discussed at the equilibrium geometry in the three media, the result show that the studied derivativ could be absorbed on carbon steel surface with very good inhibition efficiency by offering electrons from the rich hetero-atoms nitrogen, oxygen, sulfur, and electrons of isatin ring to the unoccupied d-orbitals of Fe metal forming anti-bonding orbital-feedback bonds and also experimental studies of carbon steel corrosion inhibition in $3.5 \% \mathrm{NaCl}$ solution by (5BID) was account using potentiodynamic polarization, SEM (Scanning Electron Microscopy) and AFM (Atomic Force Microscopy) and EDS (Energy Dispersive Spectroscopy) measurements.
\end{abstract}

Keywords: Corrosion inhibitor, $3.5 \% \mathrm{NaCl}$ solution, isatin derivative.

\section{Introduction}

Corrosion is the destructive attack of a metal by chemical or electrochemical reaction with its environment. Deterioration by physical causes is not called corrosion, but is described as erosion, galling, or wear. "Rusting" applies to the corrosion of iron or iron- base alloys with formation of corrosion products consisting largely of hydrous ferric oxides. Nonferrous metals, therefore, corrode, but do not rust [1]. A corrosion inhibitor is a substance when added in a small concentration to an environment reduces the corrosion rate of a metal exposed to that environment [2]. The majority of inhibitors used in the industry are organic compounds mainly consisting of nitrogen, oxygen and sulfur, as well as inhibitors that contain double or triple bonds facilitate the adsorption of these compounds on the metal surfaces [3]. Many scientists have reported that the mechanism of inhibition is mostly explained by certain physicochemical and electronic properties of the organic inhibitor such as steric effects, functional groups, the orbital nature of donating electrons, and the electron density of the donor atoms [4,5]. Isatin is an indole derivative which has been known since. It was prepared by Erdmann and Laurent from oxidation of indigo by nitric and chromic acids [6,7]. In nature, isatin is found in plants of the genus Isatis [8], in Calanthe discolor LINDL [9] and in Couroupita guianensis Aubl [10], also it has been found as a component of the secretion from the parotid gland of Bufo frogs [11]. In humans it has been found as a metabolic derivative of adrenalin [12]. Isatin is also found in the fruits of the cannon ball tree [13]. The detection of isatin in mammalian tissues was formed probably from heme-protein bound tryptophan in an iron catalyzed oxidation reaction, led to the development of some techniques for its detection in biological samples [14]. Isatin was produced by a bacterium that lives on the surface of crustacean eggs. Isatin inhibits the growth of pathogenic fungi. Substituted isatins are also found in plants, for example the melosatin alkaloids (methoxy phenyl pentyl isatins) were obtained from the
Caribbean tumorigenic plant Melochia tomestosa [15]. Recently, various experimental and theoretical techniques have been developed to study the structural properties of inhibitor molecules and their activity toward metal surface, but the quantum chemical calculations based on density function theory (DFT) method have become an attractive theoretical method because it gives exact basic vital parameters for even huge complex molecules. Thus, DFT has become an important tool for connecting some traditional empirical concepts with quantum mechanics. Therefore, DFT is a very powerful technique to probe inhibitor/ surface interaction and to analyze experimental data. The relationships between the inhibition efficiency of the used compound in $3.5 \% \mathrm{NaCl}$ and some quantum chemical parameters such as $\mathrm{E}_{\mathrm{HOMO}}$ (Highest Occupied Molecular Orbital Energy), $\mathrm{E}_{\text {LuMO }}$ (Lowest Unoccupied Molecular Orbital Energy), the energy gap $(\Delta E)$, hardness $(\eta)$, softness $(\mathrm{S})$, dipole moment $(\mu)$, electron affinity $(\mathrm{EA})$, ionization potential(IE), the absolute electronegativity $(\chi)$, electrophilicity index $(\omega)$ and the fraction of electron transferred $(\Delta \mathrm{N})$ have been also investigated by quantum chemical calculations [16-18]. The aim of this work is to synthesize a new derivative of 5-bromo isatin (5BID), Figure 1 , and viability study to carbon surface corrosion in three media (vacuum, DMSO, and $\mathrm{H}_{2} \mathrm{O}$ ) theoretically and experimentally. 5BID was chosen theoretically among several new derivatives of 5-bromo isatin [19] to be a good corrosion inhibitor, depending on studying their quantum mechanical inhibition efficiency parameters using PM3 and DFT methods, and for proving that it is also practically carbon-steel corrosion inhibitor by studying its corrosion inhibition in $3.5 \% \mathrm{NaCl}$ solution using potentiodynamic polarization, SEM (Scanning Electron Microscopy) and AFM (Atomic Force Microscopy) and EDS (Energy Dispersive Spectroscopy) measurements. 


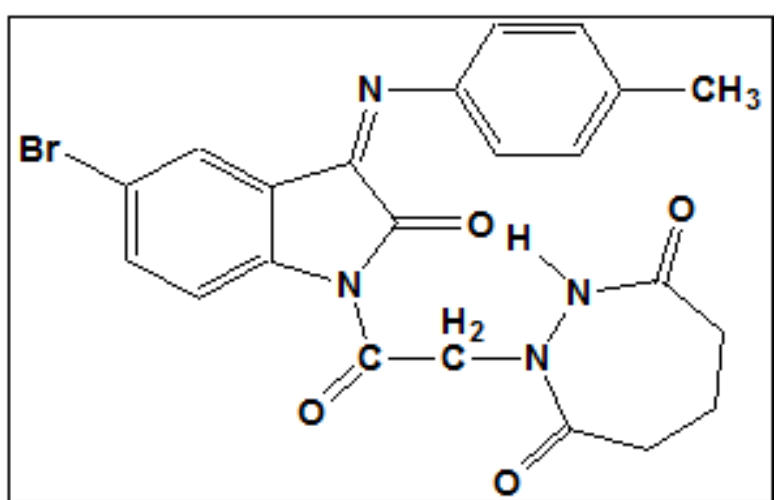

Figure 1: Chemical structure of $\mathrm{N}-[($ hexahydrodiazepine3,7-dione-1-yl)aceto]-3- (tolylimino)-5-bromo-2-oxo-indole (5BID).

\section{Materials and Methods}

Synthesis of 3-(tolyl-imino)-5-bromo indole-1H-2 one (1). A mixture of 5-bromoisatin (Indole-2,3-dione) (4.20g, $0.0186 \mathrm{~mol})$ with p-toluidine $(5.87 \mathrm{~g}, 0.0186 \mathrm{~mol})$ in dimethyl formamide $(10 \mathrm{ml})$ was refluxed for $(10 \mathrm{hrs})$ in the presence of (4-5) drops of glacial acetic acid. After cooling, it was filtered and recrystallized from dioxan solvent [20].

Synthesis of $\mathrm{N}$-( $\alpha$-chloroaceto-1-yl)-3-(P-tolyl imino)-5bromo-2-oxo- indole (2).

A mixture of 3-(tolyl imino)-5-bromo indole-1H-2-one (1 gm, $0.0031 \mathrm{~mol})$ in $(5 \mathrm{ml})$ DMF (dimethylformamide), was cooled to $\left(0{ }^{\circ} \mathrm{C}\right)$, and sodium hydride $(0.08 \mathrm{~g}, 0.0031 \mathrm{~mol}$ $60 \%$ in mineral oil) periodically added to the solution in small portions. $(0.24 \mathrm{~g}, 0.0031 \mathrm{ml})$ of chloroacetylchloride was added to the slurry via stirring, and the reaction mixture was slowly warmed to room temperature. The reaction was quenched with water after $(4.30 \mathrm{hrs})$. The resulting precipitate was removed via filtration and recrystallization from ethanol solvent [20].

Synthesis of N-(acetohydrazide-1-yl)-3-(P-tolyl imino)-5bromo-2- oxo- indole (3).

To a mixture of compound (2) N-( $\alpha$-chloroaceto-1-yl)-3- $(P$ tolyl imino)- 5-bromo-2-oxo indole, (1 g, $0.0025 \mathrm{~mol}$.) in absolute ethanol $(5 \mathrm{ml})$ with drops of DMF, was added to hydrazine hydrated $80 \%(0.07 \mathrm{ml}, 0.0025 \mathrm{~mol})$ with a continuous stirring. The resulting mixture was refluxed for (4 hrs). After cooling the mixture of deep brown precipitate was formed. The precipitate was filtered and recrystallization from ethanol solvent [21].

Synthesis of N-[(hexahydrodiazepine-3,7-dione-1yl)aceto]-3- (tolylimino)-5-bromo-2-oxo-indole (4).

A mixture of $\mathrm{N}$-(acetohydrazide-1-yl)-3-( $P$-tolyl imino)-5bromo-2- oxo- indole (3) (1 gm, $0.0025 \mathrm{~mol})$ with (glutaric anhydride) $(0.0025 \mathrm{~mol})$ in $(10 \mathrm{ml})$ of glacial acetic acid was heated under reflux for $(6-8 \mathrm{hrs})$. The mixture was cooled by adding it to ice bath.

\section{Preparation of samples}

The steel used in this study is a carbon steel (C45) with a chemical composition of metallic materials (in wt $\%$ ) of $(0.42-0.50) \%$ C, $0.40 \%$ Si, $(0.50-0.80) \% \mathrm{Mn}, 0.045 \% \mathrm{~S}$, $0.40 \% \mathrm{Cr}, 0.045 \% \mathrm{P}, 0.40 \% \mathrm{Ni}, 0.1 \%$ (Mo \& $\mathrm{Cr}$ ) and (97.31$97.96) \%$ iron $(\mathrm{Fe})$. The carbon steel samples were mechanically cut into the circular sample with dimensions of $2.5 \mathrm{~cm}$ in diameter and $0.5 \mathrm{~mm}$ thickness. Pre-treated prior to the experiments by grinding with emery paper $\mathrm{SiC}$ in different grade $(80,150,220,320,400,1000,1200$ and 2000), rinsed with tap water, distilled water and recent degreased in acetone, washed again with distilled water, dried at room temperature and keep in a desiccators before immersed in corrosive synthesis of $3.5 \% \mathrm{NaCl}$ solution $[23,24]$.

\section{Preparation solution}

\section{Blank solution}

For preparing blank solution, ( $35 \mathrm{~g}$ ) of $\mathrm{NaCl}$ was dissolve by $100 \mathrm{ml}$ of de-ionized water, transferred to a volumetric flask of $1 \mathrm{~L}$ containing $2 \mathrm{ml}$ DMSO, then the volume was completed by de-ionized water. $3.5 \% \mathrm{NaCl}$ was chosen in order to avoid the problems linked to the ohmic drop.

\section{Test solution}

The solutions concentration of (5ppm), (10ppm), (20ppm), and $(30 \mathrm{ppm})$ were prepared by dissolving $0.005 \mathrm{~g}, 0.01 \mathrm{~g}$, $0.02 \mathrm{~g}$, and $0.03 \mathrm{~g}$ of $5 \mathrm{BIN}$ respectively, each in $2 \mathrm{ml}$ DMSO, transferred to a volumetric flask of $1 \mathrm{~L}$ containing $35 \mathrm{gm}$ $\mathrm{NaCl}$, then completed the volume with de-ionized water. The precipitate product was filtered and recrystallized from chloroform solvent [22].

\section{Electrochemical measurements}

The potentiostat set up include Host computer, thermostat, magnetic stirrer, and Matlab (Germany, 2000) potentiostat, galvanostat. The corrosion cell is (1 L) capacity made of pyrex consist of two bowls internal and external. The corrosion cell is a three electrode electrochemical cell containing a carbon steel working electrode with a $1 \mathrm{~cm}^{2}$ surface. The potential of working electrode was determined according to the reference electrode. The auxiliary electrode is a platinum electrode with length of $(10 \mathrm{~cm})$ and the referenced electrode is a silver-silver chloride $(\mathrm{Ag} / \mathrm{AgCl}, 3.0$ $\mathrm{M} \mathrm{KCl})$. The working electrode was immersed in the test solution for (15 mint) to a establish steady state open circuit potential (Eocp), then electrochemical measurements were performed in potential range $( \pm 200) \mathrm{mV}$. All electrochemical tests have been performed in aerated solutions at temperatures of $(293,303,313,323$, and $333 \mathrm{~K})$.

\section{Results and Discussion}

\section{Molecular geometry}

The compound was built using Chem Draw of Mopac program Figure 2a. Gaussian 09 package was used for calculating the equilibrium geometries [25]. The corresponding geometry in the vacuum phase was fully optimized firstly using PM3 semiempirical method, then DFT (Density Functional Theory) was carried out using Becke's three-parameter functional and the correlation functional of Lee, Yang and Parr (B3LYP) with a 6-311++G (2d, 2p) level of theory [26-28] for calculating the equilibrium geometries of the investigate molecule in three media (vacuum, aqueous and dimethyl sulfoxide), all at the same level of DFT theory. The final geometry of (5BID) according to the most correct method (DFT) is given in Figure 2a. 


\section{International Journal of Science and Research (IJSR)

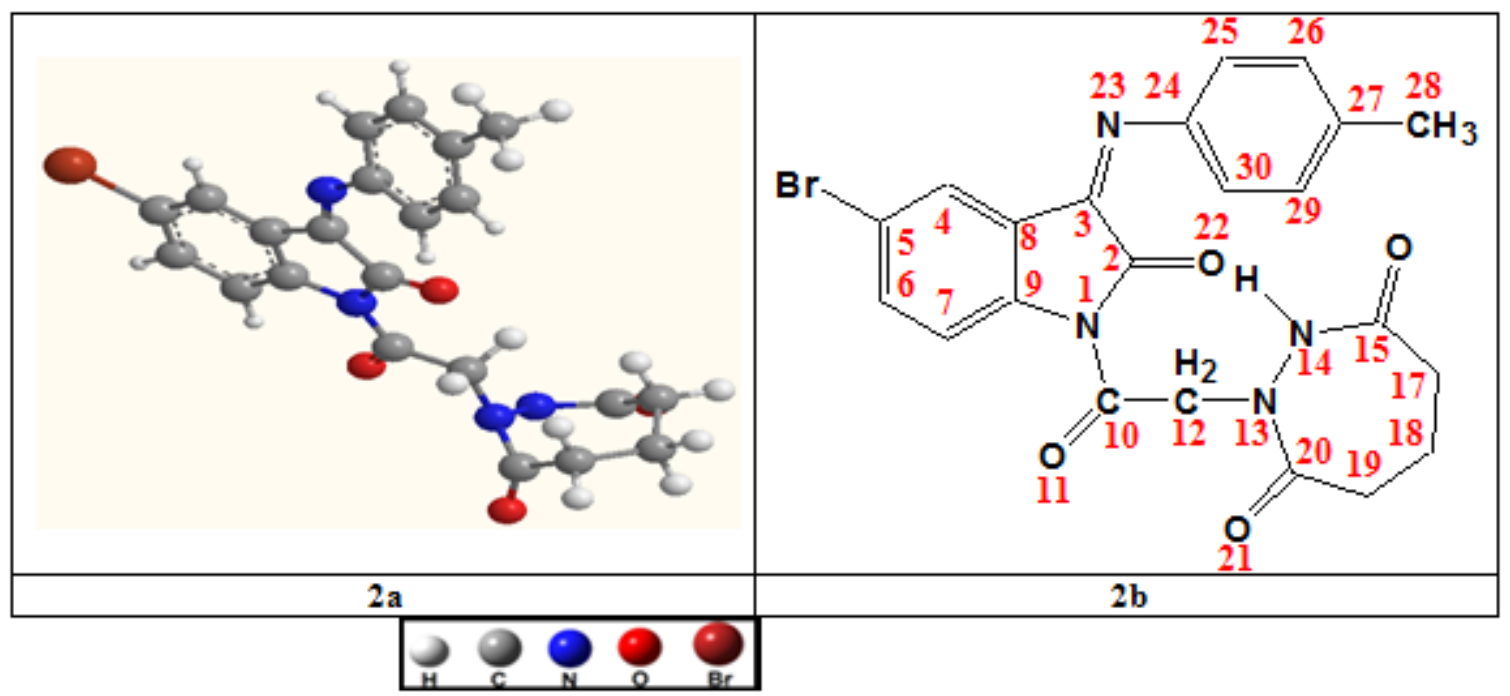

Figure 2: a- Equilibrium geometry of the 5BID molecule calculated by DFT method, b- labels for atoms of 5BID compound

Figure $2 b$ shows the label of the atoms of the studied inhibitor. The differ substitution group on C12 [(3,7-Dioxo[1,2]diazepam-1-yl)-acetaldehyde], made a difference observed in the computational results involves significant modifications on the structural parameters such as bond angles, bond distances, dihedral angles, leading to increase the inhibition parameters efficiency in comparison to Phenylethylidene and benzyl substitutions group [17,18] as a stronger electron withdrawing group [29.30]. The optimized geometrical structures of 5BID were found to be the same in the three media, the longest bond length was observed for $\mathrm{C} 5-\mathrm{Br}\left(1.921 \mathrm{~A}^{0}\right)$ which comes later for $\mathrm{C} 18-\mathrm{C} 19\left(1.553 \mathrm{~A}^{0}\right)$ and $\mathrm{C} 27-\mathrm{C} 28\left(1.503 \mathrm{~A}^{0}\right)$. The shortest bond length was observed for $\mathrm{C} 28-\mathrm{H} 31\left(1.092 \mathrm{~A}^{0}\right)$. The bond angles were getting between $\left(105.049 \mathrm{~A}^{0}\right)$ for $\mathrm{C} 2 \mathrm{C} 3 \mathrm{C} 8$ and $\left(133.180 \mathrm{~A}^{0}\right)$ for $\mathrm{C} 3 \mathrm{~N} 23 \mathrm{C} 24$. The values of the trans dihedral angles such as (C2C3C4N7), (H33C3C4C5), (C16C15C14C18), $(\mathrm{C} 5 \mathrm{C} 8 \mathrm{C} 9019)$ and for the cis dihedral angles such as (BrC5C6H32), (C4C5C6C7), (C9C5C4N7), $(\mathrm{H} 35 \mathrm{C} 12 \mathrm{C} 13 \mathrm{H} 36)$ showing the nearly planarity of this part of molecule, indicating to the easier adsorption sites of 5BID molecules on the metallic surface of carbon steel Table 1. On using solvents (water, DMSO) there is no change in the geometrical structure [31].

Table 1: Geometrical structure for (5BID) molecule by using DFT method.

\begin{tabular}{|c|c|c|c|c|c|}
\hline $\begin{array}{l}\text { Description } \\
\text { Bond length }\end{array}$ & $\begin{array}{c}\text { Bond length } \\
(\AA)\end{array}$ & $\begin{array}{l}\text { Description } \\
\text { angle (deg) }\end{array}$ & $\begin{array}{c}\text { Bond angle } \\
\text { (deg) }\end{array}$ & $\begin{array}{c}\text { Description Dihedral } \\
\text { angle (deg) }\end{array}$ & $\begin{array}{c}\text { Dihedral angle } \\
\text { (deg) }\end{array}$ \\
\hline $\mathrm{N} 1-\mathrm{C} 2$ & $1.420 \mathrm{G}$ & C7N1C9 & $130.084 \mathrm{G}$ & BrC5C6H32 & $-0.076 \mathrm{G}$ \\
\hline N1-C9 & $1.430 \mathrm{G}$ & $\mathrm{C} 2 \mathrm{~N} 1 \mathrm{C} 9$ & $109.687 \mathrm{G}$ & C4C5C6C7 & $-0.188 \mathrm{G}$ \\
\hline N1-C10 & $1.405 \mathrm{G}$ & $\mathrm{N} 1 \mathrm{C} 2 \mathrm{C} 3$ & $106.512 \mathrm{G}$ & C9C5C4N7 & $-0.575 \mathrm{G}$ \\
\hline $\mathrm{C} 2-\mathrm{C} 3$ & $1.520 \mathrm{G}$ & $\mathrm{N} 1 \mathrm{C} 2 \mathrm{O} 22$ & $124.528 \mathrm{G}$ & H35C12C13H36 & $-0.634 \mathrm{G}$ \\
\hline $\mathrm{C} 2=\mathrm{O} 22$ & $1.208 \mathrm{G}$ & $\mathrm{C} 2 \mathrm{C} 3 \mathrm{C} 8$ & $105.049 \mathrm{G}$ & C18C14C13H36 & $1.921 \mathrm{G}$ \\
\hline C3-C8 & $1.460 \mathrm{G}$ & $\mathrm{C} 2 \mathrm{C} 3 \mathrm{~N} 23$ & $132.547 \mathrm{G}$ & $\mathrm{O} 21 \mathrm{C} 17 \mathrm{C} 22 \mathrm{~N} 23$ & $-2.351 \mathrm{G}$ \\
\hline $\mathrm{C} 3-\mathrm{N} 23$ & $1.279 \mathrm{G}$ & C4C8C3 & $129.146 \mathrm{G}$ & $\mathrm{H} 45 \mathrm{C} 26 \mathrm{C} 27 \mathrm{H} 47$ & $50.946 \mathrm{G}$ \\
\hline $\mathrm{C} 4-\mathrm{C} 5$ & $1.385 \mathrm{G}$ & $\mathrm{C} 5 \mathrm{C} 4 \mathrm{C} 8$ & $117.673 \mathrm{G}$ & H44N24C29O30 & $8.38699 \mathrm{G}$ \\
\hline $\mathrm{C} 4-\mathrm{C} 8$ & $1.388 \mathrm{G}$ & C4C5Br & $119.252 \mathrm{G}$ & C1C6C5C9 & $-178.967 \mathrm{G}$ \\
\hline C5-C6 & $1.390 \mathrm{G}$ & C4C5C6 & $121.643 \mathrm{G}$ & C2C3C4N7 & $179.651 \mathrm{G}$ \\
\hline $\mathrm{C} 5-\mathrm{Br}$ & $1.921 \mathrm{G}$ & C5C6C7 & $120.652 \mathrm{G}$ & H33C3C4C5 & $-179.834 \mathrm{G}$ \\
\hline C6-C7 & $1.395 \mathrm{G}$ & C6C7C9 & $117.994 \mathrm{G}$ & N7C8C9N10 & $-174.987 \mathrm{G}$ \\
\hline C7-C9 & $1.387 \mathrm{G}$ & C4C8C9 & $121.176 \mathrm{G}$ & C16C15C14C18 & $179.300 \mathrm{G}$ \\
\hline $\mathrm{C} 10=\mathrm{O} 11$ & $1.210 \mathrm{G}$ & N1C8C9 & $109.052 \mathrm{G}$ & N7C17C22N23 & $177.919 \mathrm{G}$ \\
\hline $\mathrm{C} 10-\mathrm{C} 12$ & $1.531 \mathrm{G}$ & C2N1C10 & $126.047 \mathrm{G}$ & $\mathrm{H} 46 \mathrm{C} 26 \mathrm{C} 27 \mathrm{H} 47$ & $171.166 \mathrm{G}$ \\
\hline C12-N13 & $1.448 \mathrm{G}$ & N1C10O11 & $120.487 \mathrm{G}$ & C5C8C9O19 & $179.726 \mathrm{G}$ \\
\hline N13-N14 & $1.391 \mathrm{G}$ & $\mathrm{N} 1 \mathrm{C} 10 \mathrm{C} 12$ & $117.687 \mathrm{G}$ & ------- & ------- \\
\hline N14-C15 & $1.374 \mathrm{G}$ & C10C12N13 & $109.842 \mathrm{G}$ & ------- & ------- \\
\hline $\mathrm{C} 15=\mathrm{O} 16$ & $1.223 \mathrm{G}$ & C12N13N14 & $116.869 \mathrm{G}$ & ------- & ------- \\
\hline C15-C17 & $1.530 \mathrm{G}$ & N13N14C15 & $121.245 \mathrm{G}$ & ------- & ------- \\
\hline C17-C18 & $1.545 \mathrm{G}$ & N14C15O16 & $119.961 \mathrm{G}$ & ------- & ------- \\
\hline C18-C19 & $1.553 \mathrm{G}$ & C17C15O16 & $122.313 \mathrm{G}$ & ------- & ------- \\
\hline C19-C20 & $1.500 \mathrm{G}$ & C17C18C19 & $115.649 \mathrm{G}$ & $\begin{array}{l}------ \\
\end{array}$ & $\begin{array}{l}------- \\
\end{array}$ \\
\hline $\mathrm{C} 20=\mathrm{O} 21$ & $1.209 \mathrm{G}$ & C18C19C20 & $117.947 \mathrm{G}$ & ------- & $\begin{array}{l}------ \\
\end{array}$ \\
\hline C20-N13 & $1.432 \mathrm{G}$ & $\mathrm{C} 19 \mathrm{C} 20 \mathrm{O} 21$ & $122.313 \mathrm{G}$ & ------- & ------- \\
\hline $\mathrm{N} 23-\mathrm{C} 24$ & $1.386 \mathrm{G}$ & $\mathrm{N} 13 \mathrm{C} 20 \mathrm{O} 21$ & $119.961 \mathrm{G}$ & $\begin{array}{l}------ \\
\end{array}$ & $\begin{array}{l}------- \\
\end{array}$ \\
\hline C24-C25 & $1.409 \mathrm{G}$ & C19C20N13 & $117.680 \mathrm{G}$ & $\begin{array}{l}------ \\
\end{array}$ & ------- \\
\hline
\end{tabular}


International Journal of Science and Research (IJSR)

ISSN (Online): 2319-7064

Index Copernicus Value (2015): 78.96 | Impact Factor (2015): 6.391

\begin{tabular}{|c|c|c|c|c|c|}
\hline C25-C26 & $1.383 \mathrm{G}$ & C3N23C24 & $133.180 \mathrm{G}$ & ------- & $\begin{array}{l}----\cdot \\
--1\end{array}$ \\
\hline C26-C27 & $1.399 \mathrm{G}$ & $\mathrm{N} 23 \mathrm{C} 24 \mathrm{C} 25$ & $114.302 \mathrm{G}$ & $\begin{array}{l}------ \\
\end{array}$ & $\begin{array}{ll}----\cdot \\
\end{array}$ \\
\hline C27-C28 & $1.503 \mathrm{G}$ & C26C27C29 & $117.904 \mathrm{G}$ & ------- & ----- \\
\hline C27-C29 & $1.400 \mathrm{G}$ & $\mathrm{C} 27 \mathrm{C} 29 \mathrm{C} 30$ & $121.868 \mathrm{G}$ & ------- & $\begin{array}{ll}---\cdot \\
\end{array}$ \\
\hline C29-C30 & $1.385 \mathrm{G}$ & C29C30C24 & $120.166 \mathrm{G}$ & ------- & ----- \\
\hline C30-C24 & $1.408 \mathrm{G}$ & C30C24N23 & $127.722 \mathrm{~W}$ & ------- & ----- \\
\hline C28-H31 & $1.092 \mathrm{G}$ & $\mathrm{C} 27 \mathrm{C} 28 \mathrm{H} 31$ & $110.505 \mathrm{~W}$ & ------- & ----- \\
\hline
\end{tabular}

\section{Global molecular reactivity:}

To investigate the effect of molecular structure on the inhibition mechanism and inhibition efficiency, some quantum chemical calculations were performed. Quantum chemical parameters such as $\left(\mathrm{E}_{\text {Hомо }}\right),\left(\mathrm{E}_{\mathrm{LUMO}}\right)$ Figure 3, HOMO-LUMO energy gap $\left(\Delta \mathrm{E}_{\text {gap }}\right)$, the dipole moment $(\mu)$ of the optimized structure of the inhibitor 5BID had been calculated, Table 2. Frontier molecular orbital theory suggests that the formation of a transition state is due to the interaction between frontier orbitals (HOMO and LUMO) of the reacting species. It is well-known that low absolute values of the energy band gap gives good inhibition efficiencies, because the ionization potential will be low [32]. The dipole moment $(\mu)$ is a measure of the polarity of a covalent bond, which is related to the distribution of electrons in a molecule [33]. It is generally agreed that the large values of $\mu$ leads to the adsorption of inhibitor, and $\mu$ can be used as a predictor for the direction of a corrosion inhibition reaction [34]. The dipole moments of 5BID (6.2554 Debye), in the vacuum phase for PM3 method and (8.2268 Debye) for DFT method Tables $(2,4)$, increasing in dimethyl sulfoxide and aqueous solution, indicates a strong dipole-dipole interactions between metallic surface and 5BID compound. The N-benzyl-5-bromoisatin derivative adsorption in aqueous solution can be regarded as a quasisubstitution process of the DMSO and water molecules by the inhibitors molecules at the metal surface $\left(\mathrm{H}_{2} \mathrm{O}\right.$ ads). According to Koopman's theorem, there is a way to correlate inhibition efficiency with parameters of molecular structure to calculate the fraction of electrons transferred from inhibitor to metal surface [35]. The ionization potential (I) and the electron affinity (A), absolute electronegativity $(\chi)$ and global hardness $(\eta)$ can be obtained by using equations $(1,2,3)[36]$.

$$
\begin{aligned}
& \mathrm{I}=-\mathrm{E}_{\mathrm{HOMO}} \\
& \mathrm{A}=-\mathrm{E}_{\mathrm{LUMO}} \\
& \chi=\frac{\mathrm{I+A}}{2}
\end{aligned}
$$

The fraction of electrons transferred from the inhibitor to metallic surface, $\Delta \mathrm{N}$, can be calculated using equation 4 [37], with the theoretical values of of $\chi \mathrm{Fe}\left(7 \mathrm{eV} \mathrm{mol}^{-1}\right)$ and $\eta \mathrm{Fe}$ of $\left(0 \mathrm{eV} \mathrm{mol}^{-1}\right)$ [38].

$$
\Delta \mathrm{N}=\frac{\chi_{F e}-x_{\text {inh }}}{2\left(\eta_{\mathrm{Fe}}+\eta_{\mathrm{inh}}\right)}
$$

Global chemical softness (S), and Global electrophilicity index $(\omega)$, was estimated by using the following equations:

$$
\begin{aligned}
& S=1 / \eta \ldots \\
& \omega=(-x)^{2} / 2 \eta=\mu^{2} / 2 \eta
\end{aligned}
$$

The calculated results are presented in Tables $(3,5)$. Generally, value of $\Delta \mathrm{N}$ shows the inhibition efficiency resulting from electron donation. The inhibition efficiency increases with increasing the electron-donating ability to the metal surface. Value of $\Delta \mathrm{N}$ shows inhibition effect resulted from electrons donation. According to Lukovits's study [39], if $\Delta \mathrm{N}<3.6$, the inhibition efficiency increases with increasing electron-donating ability at the metal surface.

Table 2: PM3 calculations for some physical properties of the inhibitor molecule 5BID at the equilibrium geometry

\begin{tabular}{|c|c|c|c|c|c|}
\hline $\begin{array}{c}\text { M. formula } \\
\mathrm{M} . w t(\mathrm{gm} / \mathrm{mol})\end{array}$ & $\begin{array}{c}\Delta \mathrm{H}_{\mathrm{f}}^{0}(\mathrm{kcal} / \mathrm{mol}) \\
(\mathrm{kJ} / \mathrm{mol})\end{array}$ & $\begin{array}{c}\mathrm{E}_{\mathrm{HOMO}} \\
(\mathrm{eV})\end{array}$ & $\begin{array}{c}\mathrm{E}_{\mathrm{LUMO}} \\
(\mathrm{eV})\end{array}$ & $\begin{array}{c}\Delta \mathrm{E}(\mathrm{eV}) \\
\text { HOMO-LUMO }\end{array}$ & $\mu($ Debye $)$ \\
\hline $\begin{array}{c}\mathrm{C}_{22} \mathrm{H}_{19} \mathrm{~N}_{4} \mathrm{O}_{4} \mathrm{Br} \\
483.321\end{array}$ & $\begin{array}{c}-42.866 \\
-179.351\end{array}$ & -9.242 & -1.558 & 7.684 & 6.2554 \\
\hline
\end{tabular}

Table 3: Quantum chemical parameters for the inhibitor molecules as calculated using PM3 method

\begin{tabular}{|c|c|c|c|c|c|c|}
\hline $\mathrm{IE}(\mathrm{eV})$ & $\mathrm{EA}(\mathrm{eV})$ & $\eta(\mathrm{eV})$ & $\chi(\mathrm{eV})$ & $\mathrm{S}(\mathrm{eV})$ & $\boldsymbol{\omega}(\mathrm{eV})$ & $\Delta \mathrm{N}$ \\
\hline 9.242 & 1.558 & 3.8420 & 5.4000 & 0.2602 & 3.7948 & 0.2082 \\
\hline
\end{tabular}

Table 4: DFT calculations for some physical properties of the 5BID inhibitor molecule in the three media (vacuum, DMSO, and $\mathrm{H}_{2} \mathrm{O}$ ) at the equilibrium geometriy

\begin{tabular}{|l|c|c|c|c|c|c|c|}
\hline Inhib. & $\mathrm{IE}(\mathrm{eV})$ & $\mathrm{EA}(\mathrm{eV})$ & $\eta(\mathrm{eV})$ & $\chi(\mathrm{eV})$ & $\mathrm{S}(\mathrm{eV})$ & $\boldsymbol{\omega}(\mathrm{eV})$ & $\Delta \mathrm{N}$ \\
\hline Vacuum & 6.6338 & 3.4514 & 1.5912 & 5.0426 & 0.6284 & 7.9901 & 0.6150 \\
\hline DMSO & 6.4520 & 3.2487 & 1.6016 & 4.8503 & 0.6243 & 7.3443 & 0.6711 \\
\hline $\mathrm{H}_{2} \mathrm{O}$ & 6.4499 & 3.2460 & 1.6019 & 4.8479 & 0.6242 & 7.3357 & 0.6717 \\
\hline
\end{tabular}

Table 5: Quantum chemical parameters for the 5BID inhibitor molecule in the three media (vacuum, DMSO, and $\mathrm{H}_{2} \mathrm{O}$ ) as calculated using DFT method

\begin{tabular}{|c|c|c|c|c|c|c|}
\hline Inhib. & Sym. & $\begin{array}{c}\mathrm{E}_{\text {HOMO }} \\
(\mathrm{eV})\end{array}$ & $\begin{array}{c}\mathrm{E}_{\text {LUMO }} \\
(\mathrm{eV})\end{array}$ & $\begin{array}{c}\Delta \mathrm{E}_{\text {HOMO-LUMO4 }} \\
(\mathrm{eV})\end{array}$ & $\begin{array}{c}\mu \\
(\text { Debye })\end{array}$ & $\begin{array}{c}\text { Etotal } \\
(\mathrm{eV})\end{array}$ \\
\hline Vacuum & $\mathrm{C} 1$ & -6.6338 & -3.4514 & 3.1824 & 8.2268 & -107327.7287 \\
\hline $\mathrm{DMSO}$ & $\mathrm{C} 1$ & -6.4520 & -3.2487 & 3.2033 & 10.5720 & -107328.3372 \\
\hline $\mathrm{H}_{2} \mathrm{O}$ & $\mathrm{C} 1$ & -6.4499 & -3.2460 & 3.2039 & 10.6106 & -107328.3468 \\
\hline
\end{tabular}




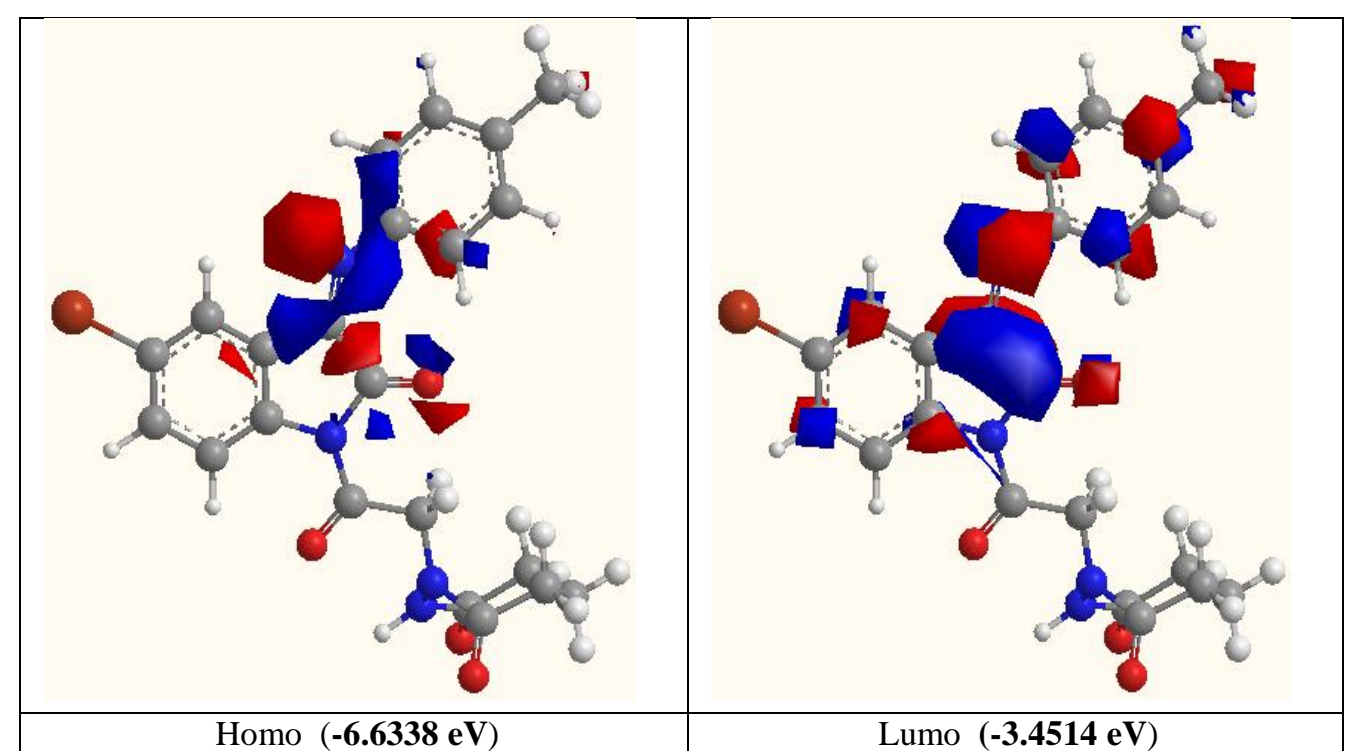

Figure 3: The Frontier molecule orbital density distributions of 5BID as calculations using DFT method. Red color indicates the negatively charged lobe, blue color indicates the positive charge lobe

Local reactivity of the one $\mathrm{N}$-benzyl-5-bromo isatin derivative

Investigated the studied inhibitors is through an indication of the reactive centers of molecules (nucleophilic and electrophilic centers) using the DFT Mulliken charges population analysis. The molecule regions where the electronic charge is large are chemically softer than the regions where the electronic charge is small, so the electron density plays an important role in calculating the chemical reactivity. Chemical adsorption interactions are either by orbital interactions or electrostatic. Electrical charges in the molecule considered driving force of electrostatic interactions. Proven charges are important in physicchemical properties of compound reactions [40,41]. Table 6 shows that the negative active sites for adsorption (Nucleophihic reactive sites) are $\mathrm{N} 14>\mathrm{O} 16>\mathrm{O} 12>\mathrm{O} 11$, and the positive active sites for adsorption (Electrophihic reactive sites) are $\mathrm{C} 20>\mathrm{N} 13>\mathrm{C} 15>\mathrm{C} 10$.

Table 6: DFT Mulliken charges population analysis for the calculated inhibitor molecules 5BID in the three media (vacuum,

DMSO, and $\mathrm{H}_{2} \mathrm{O}$ ).

\begin{tabular}{|c|c|c|c|c|c|}
\hline Amot & $\begin{array}{c}\text { Electronic } \\
\text { charge (ecu) }\end{array}$ & $\operatorname{mot} A$ & $\begin{array}{c}\text { Electronic } \\
\text { charge (ecu) }\end{array}$ & $\operatorname{mot} A$ & $\begin{array}{c}\text { Electronic } \\
\text { charge }(\mathrm{ecu})\end{array}$ \\
\hline N1 & $\begin{array}{c}-0.146 V \\
-0.116 D \\
-0.115 W \\
\end{array}$ & $\mathrm{C} 12$ & $\begin{array}{l}-0.288 V \\
-0.286 D \\
-0.286 W \\
\end{array}$ & $\mathrm{C} 24$ & $\begin{array}{c}-0.040 V \\
-0.011 D \\
-0.011 W \\
\end{array}$ \\
\hline $\mathrm{C} 2$ & $\begin{array}{l}0.122 \mathrm{~V} \\
0.169 \mathrm{D} \\
0.170 \mathrm{~W}\end{array}$ & N13 & $\begin{array}{c}0.395 V \\
0.356 D \\
0.355 W\end{array}$ & $\mathrm{C} 25$ & $\begin{array}{c}0.081 \mathrm{~V} \\
0.048 D \\
0.048 W\end{array}$ \\
\hline C3 & $\begin{array}{c}0.016 \mathrm{~V} \\
0.044 \mathrm{D} \\
0.045 \mathrm{~W}\end{array}$ & N14 & $\begin{array}{l}-0.615 \mathrm{~V} \\
-0.587 \mathrm{D} \\
-0.586 \mathrm{~W}\end{array}$ & $\mathrm{C26}$ & $\begin{array}{l}-0.245 \mathrm{~V} \\
-0.279 \mathrm{D} \\
-0.279 \mathrm{~W}\end{array}$ \\
\hline $\mathrm{C} 4$ & $\begin{array}{l}-0.169 V \\
-0.144 D \\
-0.143 W\end{array}$ & C15 & $\begin{array}{l}0.345 \mathrm{~V} \\
0.390 \mathrm{D} \\
0.390 \mathrm{~W}\end{array}$ & C27 & $\begin{array}{l}0.311 \mathrm{~V} \\
0.309 \mathrm{D} \\
0.309 \mathrm{~W}\end{array}$ \\
\hline C5 & $\begin{array}{l}-0.137 \mathrm{~V} \\
-0.169 \mathrm{D} \\
-0.170 \mathrm{~W}\end{array}$ & 016 & $\begin{array}{l}-0.481 \mathrm{~V} \\
-0.573 \mathrm{D} \\
-0.574 \mathrm{~W}\end{array}$ & $\mathrm{C} 28$ & $\begin{array}{l}-0.354 \mathrm{~V} \\
-0.367 \mathrm{D} \\
-0.367 \mathrm{~W}\end{array}$ \\
\hline $\mathrm{Br}$ & $\begin{array}{c}-0.061 \mathrm{~V} \\
-0.071 \mathrm{D} \\
-0.071 \mathrm{~W}\end{array}$ & C17 & $\begin{array}{c}-0.037 V \\
-0.050 D \\
-0.051 W\end{array}$ & C29 & $\begin{array}{c}-0.193 V \\
-0.212 D \\
-0.212 W\end{array}$ \\
\hline C6 & $\begin{array}{l}-0.368 V \\
-0.356 D \\
-0.356 W\end{array}$ & C18 & $\begin{array}{l}-0.324 V \\
-0.319 D \\
-0.319 W\end{array}$ & C30 & $\begin{array}{l}-0.223 V \\
-0.241 D \\
-0.242 W\end{array}$ \\
\hline C7 & $\begin{array}{l}-0.211 V \\
-0.227 D \\
-0.227 W\end{array}$ & C19 & $\begin{array}{l}-0.067 \mathrm{~V} \\
-0.068 \mathrm{D} \\
-0.068 \mathrm{~W}\end{array}$ & $\mathbf{N} 23$ & $\begin{array}{l}-0.191 V \\
-0.230 D \\
-0.231 W\end{array}$ \\
\hline C8 & $\begin{array}{c}0.297 \mathrm{~V} \\
0.270 \mathrm{D} \\
0.269 \mathrm{~W} \\
\end{array}$ & $\mathrm{C20}$ & $\begin{array}{c}0.486 \mathrm{~V} \\
0.519 \mathrm{D} \\
0.519 \mathrm{~W} \\
\end{array}$ & 011 & $\begin{array}{l}-0.431 \mathrm{~V} \\
-0.487 \mathrm{D} \\
-0.488 \mathrm{~W} \\
\end{array}$ \\
\hline C9 & $\begin{array}{l}0.352 \mathrm{~V} \\
0.337 \mathrm{D} \\
0.337 \mathrm{~W}\end{array}$ & 021 & $\begin{array}{c}-0.417 \mathrm{~V} \\
-0.498 \mathrm{D} \\
-0.500 \mathrm{~W}\end{array}$ & $\mathbf{O 2 2}$ & $\begin{array}{c}-0.408 \mathrm{~V} \\
-0.430 \mathrm{D} \\
-0.430 \mathrm{~W}\end{array}$ \\
\hline
\end{tabular}

Volume 6 Issue 7, July 2017 www.ijsr.net 
International Journal of Science and Research (IJSR)

ISSN (Online): 2319-7064

Index Copernicus Value (2015): 78.96 | Impact Factor (2015): 6.391

\begin{tabular}{|l|l|l|l|l|l|}
\hline C10 & $\begin{array}{l}0.308 \mathrm{~V} \\
0.340 \mathrm{D}\end{array}$ & & & & \\
& $0.340 \mathrm{~W}$ & & & & \\
\hline
\end{tabular}

$\mathrm{V}$ : vacuum phase, D: dimethyl sulfoxide (DMSO), W: water, blue color: increase in electronic charge to more positive, red color: increase in electronic charge to more negative.

Synthesis of of 3-(tolyl-imino) -5-bromo indole-1H-2-one (1).

A mixture of 5-bromoisatin (indole-2,3-dione) and para methyl aromatic amine in dimethylformamide was refluxed in the presence of glacial acetic acid to give compound (1) as shown in Scheme 1. The first step is the condensation reaction between para methyl aromatic amine and carbonyl compounds involved nucleophilic addition of para methyl aromatic amine compound to a carbonyl group producing intermediate which eliminate water molecule in step two [42] to afford the compound (1), Scheme 2.

Synthesis of N-( $\alpha$-chloroaceto-1-yl)-3-(P-tolyl imino $)-5-$ bromo-2-oxo indole (2).

A mixture of 3-(tolyl imino)-5-bromo indole-1H-2-one compound (1) in dimethylformamide (DMF), and sodium hydride was periodically added to the solution in small portions of chloroacetylchloride to give compound (2), Scheme 3 [43].

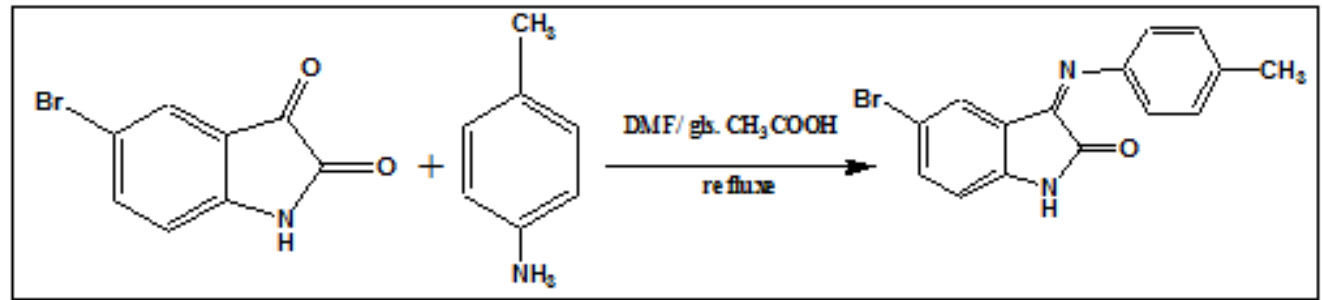

Scheme 1: Synthesis of 3-(tolyl-imino) -5-bromo indole-1H-2-one

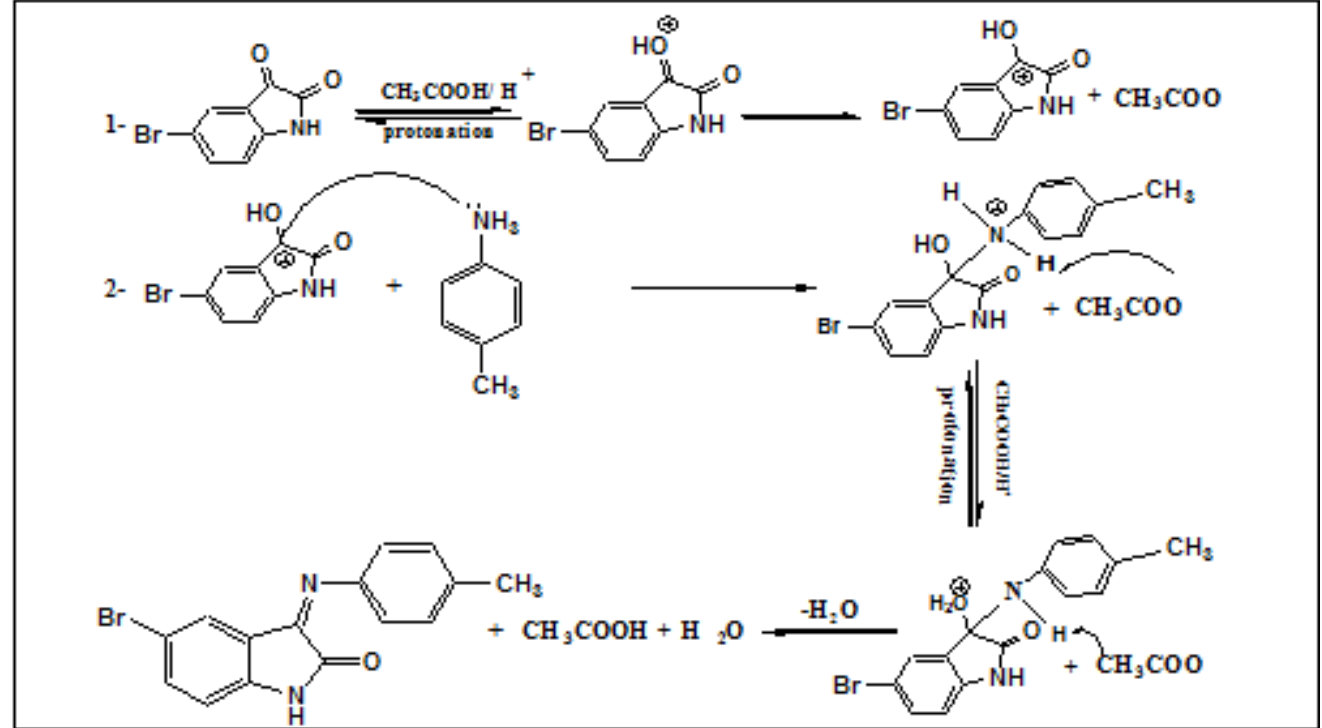

Scheme 2: Mechanical of the synthesis of 3-(tolyl-imino) -5-bromo indole-1H-2-one

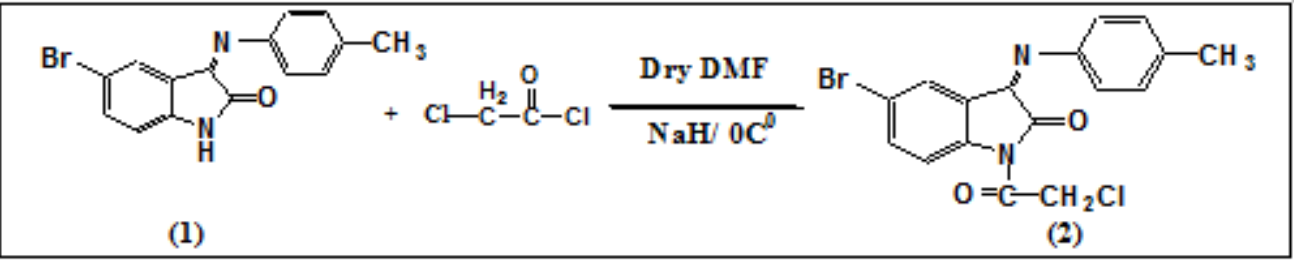

Scheme 3: Synthesis of N-( $\alpha$-chloroaceto-1-yl)-3-(P-tolyl imino)-5- bromo-2-oxo indole

Compound (2) was synthesized by nucleophilic substitution reaction of compound (1) with chloroacetylchloride. This reaction was carried out in sodium hydride $(\mathrm{NaH})$ solution to increase the nucleophilicity of indole in attacking molecule by forming sodium salt as an intermediate [44], Scheme 4.

Synthesis of N-(acetohydrazide-1-yl)-3-(P-tolyl imino)-5bromo-2-oxoindole (3).

The N-(acetohydrazide-1-yl)-3-(P-tolyl imino)-5-bromo-2oxoindole (3) was found a suitable route for this synthetic approach. So when compound (2) was refluxed with hydrazine hydrate in dimethylformamide as a solvent it gave the expected compound (3), Scheme 5.

3.7- Synthesis of N-[(hexahydrodiazepine-3,7-dione-1yl)aceto]-3-(tolylimino)-5-bromo-2-oxo-indole[4]

This compound was synthesized by the reaction of the $\mathrm{N}$ (acetohydrazide-1-yl)-3-(P-tolyl imino)-5-bromo-2oxoindole (3), with (glutaric anhydride) in the presence of

Volume 6 Issue 7, July 2017 www.ijsr.net 


\section{International Journal of Science and Research (IJSR) \\ ISSN (Online): 2319-7064 \\ Index Copernicus Value (2015): 78.96 | Impact Factor (2015): 6.391}

acetic acid as a solvent and catalyst. The compound was summarized in Scheme 6. The suggested mechanism for the synthesis of the previous derivative explained by a general mechanism [43]. The physical properties of compound (4) are listed in Table 7, and the FTIR spectral data of and HNMR signals (ppm) for this compound are listed in Table 8 .

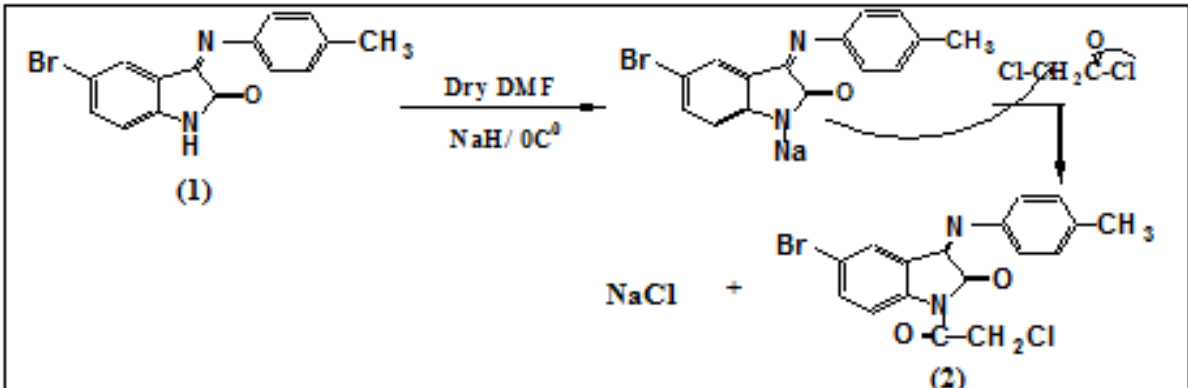

Scheme 4: Synthesis mechanism for compound (2)

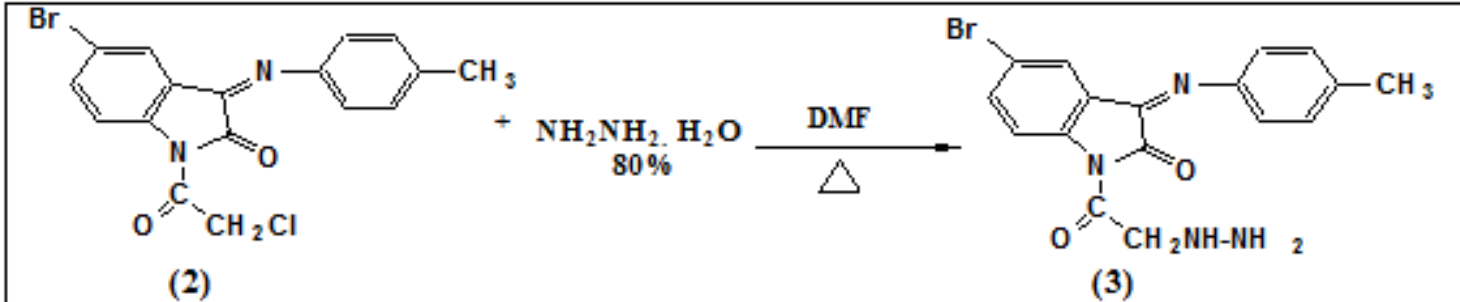

Scheme 5: Synthesis of N-(acetohydrazide-1-yl)-3-(P-tolyl imino)-5-bromo-2-oxoindole

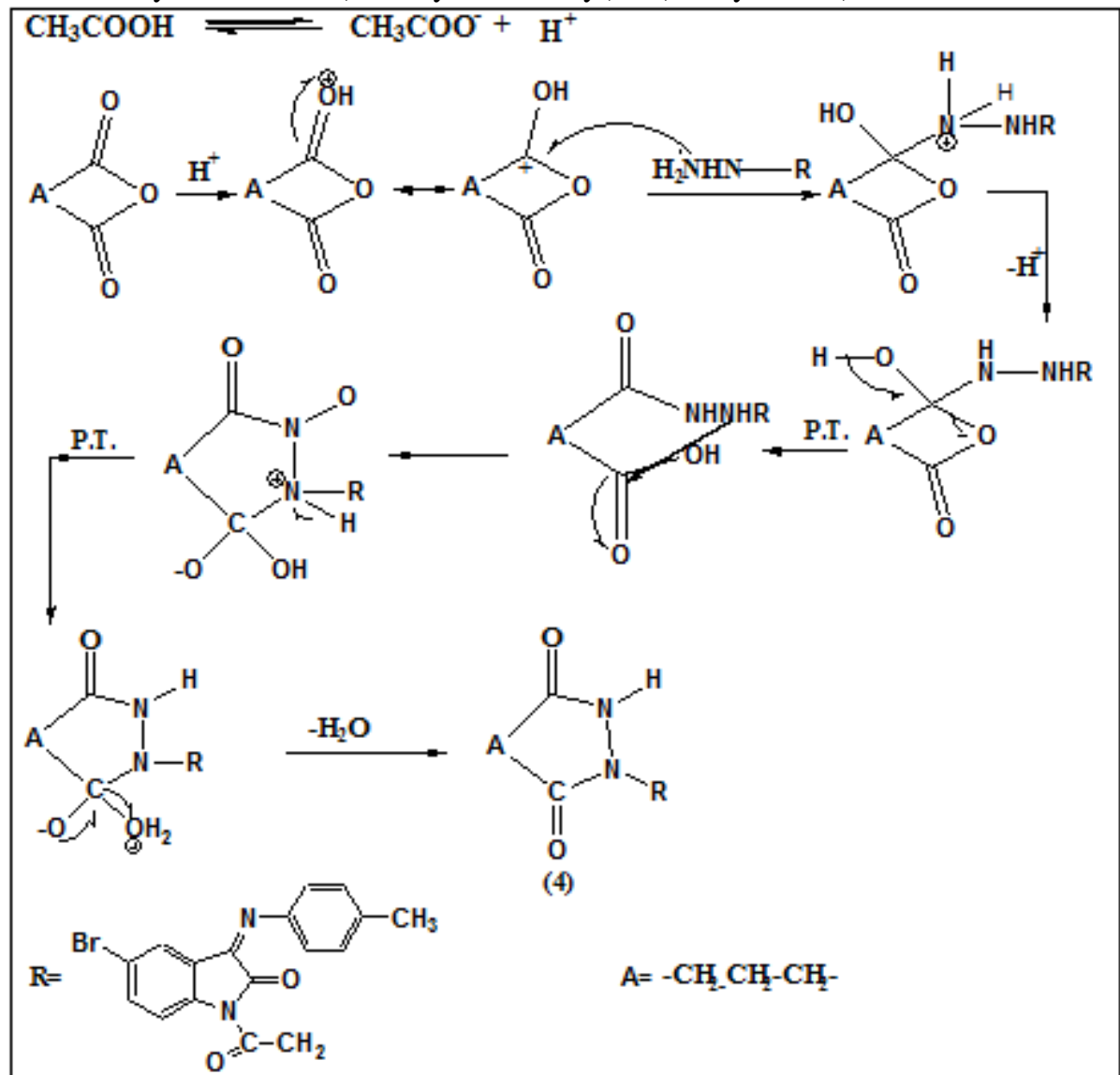

Scheme 6: Mechanical of the synthesis of N-[(hexahydrodiazepine-3,7-dione-1-yl) aceto]-3-(tolylimino)-5-bromo-2-oxoindole (PQPS).

Table 7: Physical properties of PQPS compound

\begin{tabular}{|c|c|c|c|c|c|}
\hline $\begin{array}{c}\text { Molecular } \\
\text { formula }\end{array}$ & $\begin{array}{c}\text { M.W } \\
\text { g/mol }\end{array}$ & $\begin{array}{c}\text { m.p } \\
{ }^{\circ} \mathrm{C}\end{array}$ & $\begin{array}{c}\text { Yield } \\
\%\end{array}$ & Color & $\begin{array}{c}\text { Solvent of } \\
\text { recryst. }\end{array}$ \\
\hline $\mathrm{C}_{22} \mathrm{H}_{19} \mathrm{BrN}_{4} \mathrm{O}_{4}$ & 483.3 & $165-167$ & 80 & Brown & $\mathrm{CHCl}_{3}$ \\
\hline
\end{tabular}

Volume 6 Issue 7, July 2017 www.ijsr.net 


\section{International Journal of Science and Research (IJSR) \\ ISSN (Online): 2319-7064 \\ Index Copernicus Value (2015): 78.96 | Impact Factor (2015): 6.391}

Table 8: FTIR absorption bands and HNMR signals for PQPS compound

\begin{tabular}{|c|c|c|c|c|c|}
\hline \multicolumn{6}{|c|}{ FTIR spectral data $\mathrm{cm}^{-1}$} \\
\hline$v \mathrm{~N}-\mathrm{H}$ & $\begin{array}{l}\nu(\mathrm{C}-\mathrm{H}) \\
\text { Arom. }\end{array}$ & $\begin{array}{c}v(\mathrm{C}- \\
\mathrm{H}) \\
\text { aliph. }\end{array}$ & $v(\mathrm{C}=\mathrm{O})$ & $\square(\mathrm{C}=\mathrm{N})$ & Others \\
\hline 3210 & 3070 & $\begin{array}{l}2923 \\
2852\end{array}$ & $\begin{array}{l}1712 \\
1687\end{array}$ & 1665 & $\begin{array}{c}\nu \mathrm{C}-\mathrm{Br} \\
700\end{array}$ \\
\hline \multicolumn{6}{|c|}{ HNMR signals (ppm) } \\
\hline & & & $\begin{array}{l}(\mathrm{s}, 2 \mathrm{H},-\mathrm{C} \\
\mathrm{r}-\mathrm{H})\end{array}$ & $2-) ; 7.05$ & $5(\mathrm{~m}$, \\
\hline
\end{tabular}

\section{Corrosion inhibition process}

\section{Inhibitor Concentrations}

The inhibition efficiency for each prepared concentration (5, $10,20,30 \mathrm{ppm})$ were measured at a temperatures of (293, $303,313,323$ and $333 \mathrm{~K})$. The optimum condition was found to be at $(20 \mathrm{ppm})$ and $(293 \mathrm{~K})$. Other concentrations were also measured at the different temperatures for the thermodynamic properties.

\section{Polarization Measurements}

Potentiodynamic polarization curves and Corrosion kinetic

The polarization behavior of carbon steel in $3.5 \% \mathrm{NaCl}$ solutions without and with different concentrations of 5BID are shown in Figure 4, of the supporting information. The electrochemical parameters such as Icorr, Ecorr, and Tafel slopes $(\beta c),(\beta a)$ were calculated by extrapolating the Tafel lines to the corresponding corrosion potential, IE\%, CRcorr, $\boldsymbol{\Theta}$, can be calculated using the following Equations:

$$
\begin{aligned}
& \% \mathbf{I E}=\left(\mathrm{I}_{\text {corr }(\text { un })}-\mathrm{I}_{\text {corr (in) }} / \mathrm{I}_{\text {corr }(\text { un })}\right) \times 100 \\
& \text { CRcorr }=I_{\text {corr }} \times 0.249 \\
& \boldsymbol{\Theta}=\% \mathbf{I E} / 100
\end{aligned}
$$

The results listed in Table 9 showing the increasing in the inhibition efficiency with the increase in temperature which may be attributed to the formation of a barrier film, prevents the attack of $3.5 \% \mathrm{NaCl}$ on the metal surface [46]. The best inhibition efficiency was about $99.83 \%$ at the concentration of $20 \mathrm{ppm}$ and temperature of $293 \mathrm{~K}$ at which the corrosion current is $\left(0.150 \mu \mathrm{A} \cdot \mathrm{cm}^{-2}\right)$. Also Table 9 shows that, on increasing the temperature the corrosion current Icorr is increased, while IE\% increased with increasing the temperature. Through these circumstances 5BID can be described as a mixed-type inhibitor, its inhibition is caused by adsorption, and the inhibition effect results from the reduction of the reaction area on the surface of the carbon steel [47]. Figure 4, shows the curves of Tafel anodic and cathodic polarization for the corrosion of carbon steel in a solutions of $3.5 \% \mathrm{NaCl}$, with and without the addition of $5 \mathrm{BID}$ at various concentrations.

\begin{tabular}{|c|c|c|c|c|c|c|c|c|}
\hline Solun. & $\begin{array}{c}\mathrm{T} \\
(\mathrm{K})\end{array}$ & $\begin{array}{l}E_{\text {corr }} \\
(\mathrm{mV})\end{array}$ & $\begin{array}{c}\mathrm{I}_{\text {corr }} \\
\left(\mu \mathrm{A} \cdot \mathrm{cm}^{-2}\right)\end{array}$ & $\begin{array}{c}\text { bc } \\
\left(\mathrm{mV} \cdot \mathrm{dec}^{-1}\right)\end{array}$ & $\begin{array}{c}\text { ba } \\
\left(\mathrm{mV} \cdot \mathrm{dec}^{-1}\right)\end{array}$ & IE\% & $\theta$ & CR \\
\hline \multirow{5}{*}{$\begin{array}{c}\text { Blank } \\
3.5 \% \mathrm{NaCl}\end{array}$} & 293 & -560.0 & 89.22 & -166.1 & 92.9 & ----- & ----- & 22.21 \\
\hline & 303 & -621.0 & 121.69 & -146.9 & 82.1 & ----- & ----- & 30.30 \\
\hline & 313 & -785.7 & 164.53 & -26.3 & 73.8 & ----- & ----- & 40.96 \\
\hline & 323 & -608.0 & 191.16 & -102.0 & 315.2 & ----- & ----- & 47.59 \\
\hline & 333 & -767.2 & 259.55 & -84.5 & 382.6 & ----- & ----- & 64.62 \\
\hline \multirow{5}{*}{$5 p p m$} & 293 & -848.0 & 2.35 & -14.7 & 21.4 & 97.36 & 0.973 & 0.58 \\
\hline & 303 & -768.8 & 14.96 & -111.8 & 99.5 & 87.70 & 0.877 & 3.72 \\
\hline & 313 & -726.4 & 17.42 & -122.4 & 70.9 & 89.41 & 0.894 & 4.33 \\
\hline & 323 & -733.0 & 18.38 & $\begin{array}{l}-99.7 \\
\end{array}$ & 75.2 & 90.40 & 0.904 & 4.57 \\
\hline & 333 & -948.0 & 21.17 & -62.2 & 22.0 & 91.84 & 0.918 & 5.27 \\
\hline \multirow{5}{*}{$10 \mathrm{ppm}$} & 293 & -958.9 & 21.11 & -91.8 & 65.8 & 76.33 & 0.763 & 5.25 \\
\hline & 303 & -948.8 & 18.17 & -64.1 & 49.9 & 85.06 & 0.850 & 4.52 \\
\hline & 313 & -957.8 & 23.93 & -98.0 & 46.9 & 85.45 & 0.854 & 5.95 \\
\hline & 323 & -937.5 & 27.38 & -87.4 & 55.0 & 85.67 & 0.856 & 6.81 \\
\hline & 333 & -908.7 & 29.38 & -102.3 & 44.1 & 88.68 & 0.886 & 7.31 \\
\hline \multirow{5}{*}{$20 \mathrm{ppm}$} & 293 & -546.9 & 0.150 & -84.6 & 130.1 & 99.83 & 0.998 & 0.03 \\
\hline & 303 & -958.7 & 2.66 & -56.9 & 47.8 & 97.81 & 0.978 & 0.66 \\
\hline & 313 & -937.8 & 4.36 & -49.9 & 26.5 & 97.35 & 0.973 & 1.08 \\
\hline & 323 & -946.9 & 20.80 & -103.9 & 56.1 & 89.11 & 0.891 & 5.17 \\
\hline & 333 & -938.7 & 21.09 & -108.6 & 44.0 & 91.87 & 0.918 & 5.25 \\
\hline \multirow{5}{*}{$30 \mathrm{ppm}$} & 293 & -667.7 & 5.06 & -26.4 & 22.3 & 94.32 & 0.943 & 1.25 \\
\hline & 303 & -779.1 & 16.16 & -129.9 & 86.7 & 86.72 & 0.867 & 4.02 \\
\hline & 313 & -896.1 & 20.45 & -105.1 & 34.9 & 87.57 & 0.875 & 5.09 \\
\hline & 323 & -977.4 & 22.70 & -77.3 & 43.0 & 88.12 & 0.881 & 5.65 \\
\hline & 333 & -920.4 & 22.41 & -106.4 & 78.2 & 91.36 & 0.913 & 5.58 \\
\hline
\end{tabular}

Table 9: Electrochemical data of the carbon steel corrosion in $3.5 \% \mathrm{NaCl}$ at various concentrations of 5BID and different temperature.

\section{Volume 6 Issue 7, July 2017 www.ijsr.net}




\section{International Journal of Science and Research (IJSR) \\ ISSN (Online): 2319-7064}

Index Copernicus Value (2015): 78.96 | Impact Factor (2015): 6.391

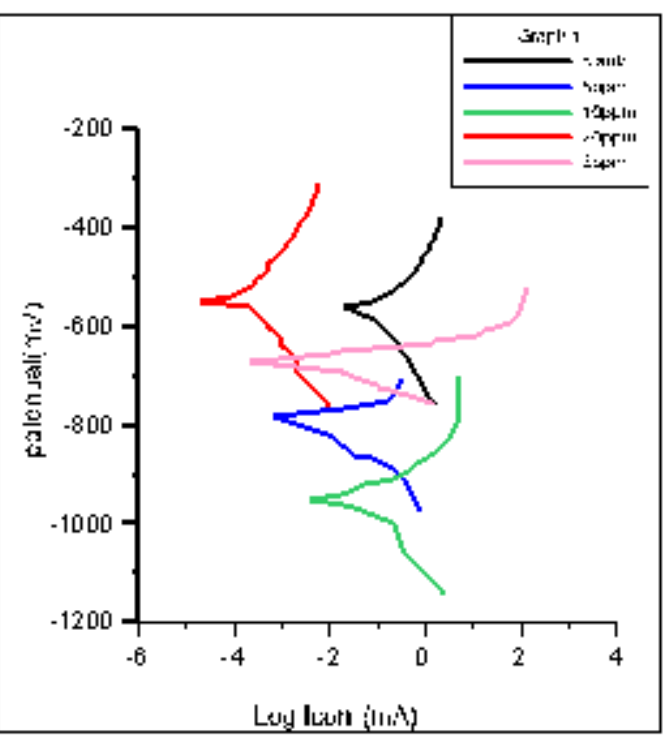

Figure 4: Polarization plots of carbon steel in $3.5 \% \mathrm{NaCl}$ for blank and 5BID inhibitor at a temperature of $293 \mathrm{~K}$ and various concentrations

Thermodynamic and activation parameters

The apparent activation energy (Ea) for dissolution of carbon steel in a $3.5 \% \mathrm{NaCl}$ solution was calculated using Arrhenius equation.

$$
\log C R=\log A-\frac{E a}{2.303 \times R T}
$$

Whereas, CR is the corrosion rate, $\mathrm{Ea}$ is the apparent activation energy of the corrosion, $\mathrm{R}$ is the molar gas constant $\left(8.314 \mathrm{~J} \mathrm{~K}^{-1} \mathrm{~mol}^{-1}\right), \mathrm{T}$ is the absolute temperature $(\mathrm{K})$ and $\mathrm{A}$ is the Arrhenius pre-exponential factor. Figure 5 presents the Arrhenius plot of log CR against 1/T for the corrosion of carbon steel in a $3.5 \% \mathrm{NaCl}$ solution in the absence and presence of the optimum concentration (20ppm) of 5BID inhibitor. The values of the standard enthalpy of activation $\left(\Delta \mathrm{H}^{*}\right)$ and standard entropy of activation $\left(\Delta S^{*}\right)$ were calculated using equation 11 :

$$
\log \frac{C R}{T}=\log \left(\frac{R}{N h}\right)+\frac{\Delta s *}{2.303}-\frac{\Delta H *}{2.303 \times R T}
$$

$\mathrm{R}$ is the universal gas constant $\left(8.314 \mathrm{~J} \cdot \mathrm{mol}^{-1} \cdot \mathrm{K}^{-1}\right), \mathrm{T}$ is the absolute temperature, $\mathrm{N}$ is the number of Avogadro's constant $\left(6.022 \times 10^{23} \mathrm{~mol}^{-1}\right), \mathrm{h}$ is the Planck's constant $(6.626$ $\left.\mathrm{x} 10^{-34} \mathrm{~J} . \mathrm{s}\right)$. A plot of $\log (\mathrm{CR} / \mathrm{T})$ against $1 / \mathrm{T}$ in the presence of 20ppm concentration of 5BID gave straight lines with a slope of $-\Delta \mathrm{H}^{*} / 2.303 \mathrm{R}$ and an intercept of $[\log (\mathrm{R} / \mathrm{Nh})+$ $\left.\left(\Delta \mathrm{S}^{*} / 2.303 \mathrm{R}\right)\right]$ Figure 6, from which the activation thermodynamic parameters $\left(\Delta \mathrm{H}^{*}\right.$ and $\left.\Delta \mathrm{S}^{*}\right)$ were calculated, Table 10. The positive sign of the enthalpy reflects the endothermic nature of the mild steel dissolution process [48, 49]. The negative value of $\Delta S^{*}$ for inhibitor indicates that the formation of the activated complex in the rate determining step represents an association rather than a dissociation step, meaning that a decrease in disorder takes place during the course of the transition from reactants to activated complex [48]. to calculate the values of $\Delta \mathrm{G}^{*}$ for the corrosion process from the following relation: $\Delta \mathrm{G}^{*}=\Delta \mathrm{H}^{*}-\mathrm{T} \Delta \mathrm{S}^{*}$. The positive value of the enthalpy $\Delta \mathrm{H}^{*}$ in the absence and presence of the optimum concentration of inhibitor reflects the endothermic nature of carbon steel activation complex forming, meaning a difficult dissolution of carbon steel.

Table 10: The activation parameters for $\mathrm{CS}$ dissolution in $3.5 \% \mathrm{NaCl}$ in the absence and presence the optimum concentration

\begin{tabular}{|c|c|c|c|c|c|c|}
\hline Solun. & $\begin{array}{c}\mathbf{T} \\
(\mathbf{K}) \\
\end{array}$ & $\begin{array}{c}\Delta \mathbf{H}^{*} \\
\left(\mathbf{k J} . \mathrm{mol}^{-1}\right)\end{array}$ & $\begin{array}{c}\Delta \mathbf{G}^{*} \\
\left(\mathrm{~kJ} . \mathrm{mol}^{-1}\right)\end{array}$ & $\begin{array}{c}\Delta \mathbf{S}^{*} \\
\left(\mathrm{~kJ} . \mathrm{mol}^{-1} \cdot \mathrm{K}^{-1}\right)\end{array}$ & $\begin{array}{c}\text { Ea } \\
\left(\mathbf{k J} . \mathrm{mol}^{-1}\right)\end{array}$ & $\begin{array}{c}\text { A (Molecules) } \\
\left(\mathrm{cm}^{-2} \cdot \mathrm{s}^{-1}\right)\end{array}$ \\
\hline \multirow{5}{*}{$\begin{array}{l}\text { Blank } \\
3.5 \% \\
\text { NaCl }\end{array}$} & 293 & \multirow{5}{*}{18.424} & 88.451 & \multirow{5}{*}{-0.239} & \multirow{5}{*}{21.020} & \multirow{5}{*}{$7.57873 \mathrm{E}+28$} \\
\hline & 303 & & 90.841 & & & \\
\hline & 313 & & 93.231 & & & \\
\hline & 323 & & 95.621 & & & \\
\hline & 333 & & 98.011 & & & \\
\hline \multirow{5}{*}{$\begin{array}{l}\text { 20ppm } \\
\text { (5BID) }\end{array}$} & 293 & \multirow{5}{*}{60.863} & 147.005 & \multirow{5}{*}{-0.294} & \multirow{5}{*}{44.255} & \multirow{5}{*}{$5.43997 \mathrm{E}+32$} \\
\hline & 303 & & 149.954 & & & \\
\hline & 313 & & 152.885 & & & \\
\hline & 323 & & 155.825 & & & \\
\hline & 333 & & 158.765 & & & \\
\hline
\end{tabular}
of the 5BID inhibitor

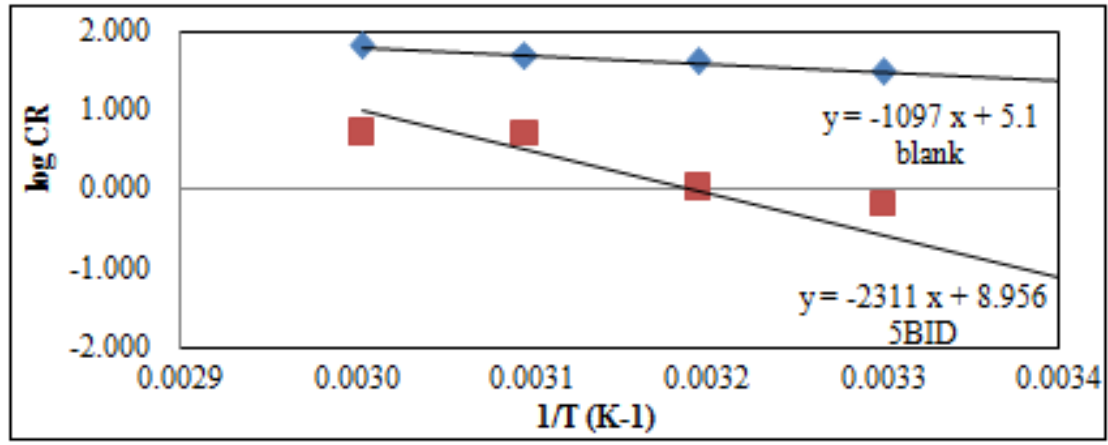

Figure 5: Plot of $\log \mathrm{CR}$ vs $1 / \mathrm{T}$ for the corrosion of $\mathrm{CS}$ in $3.5 \% \mathrm{NaCl}$ at the optimum condition of $5 \mathrm{BID}$ inhibitor within the blank 
International Journal of Science and Research (IJSR)

ISSN (Online): 2319-7064

Index Copernicus Value (2015): 78.96 | Impact Factor (2015): 6.391
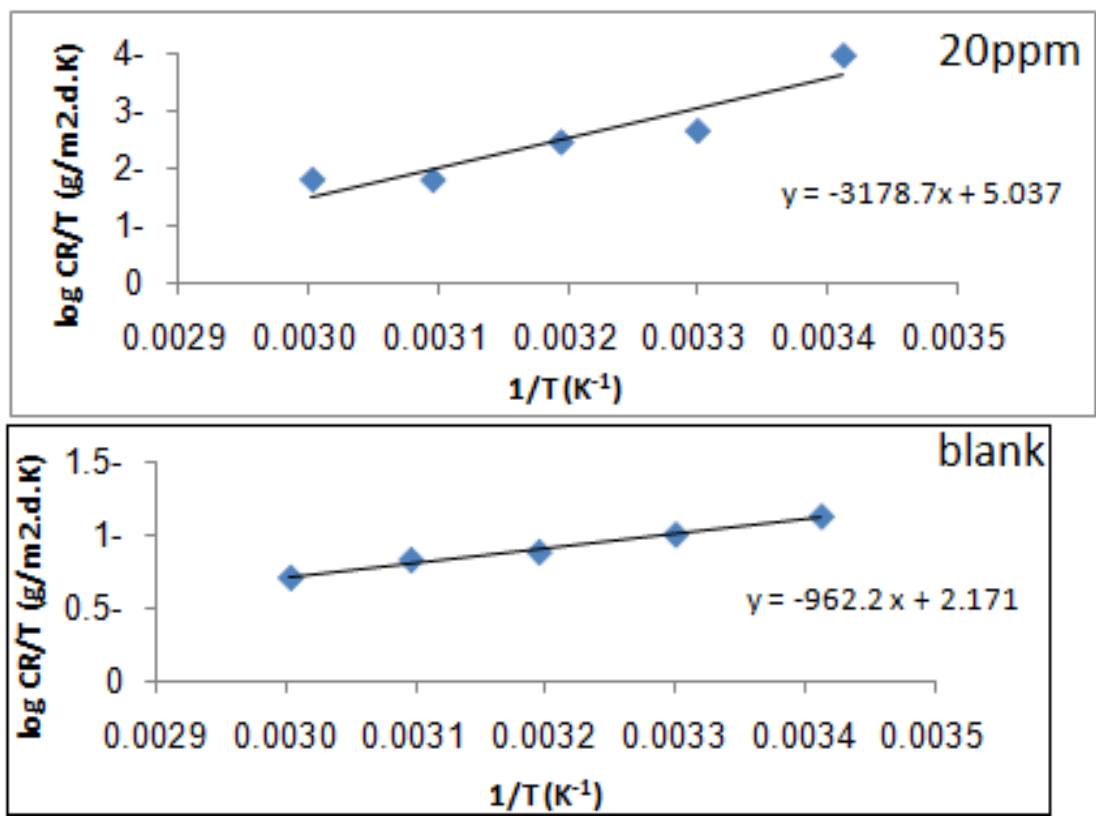

Figure 6: Arrhenius plots calculated from corrosion rate of $\mathrm{CS}$ in $3.5 \% \mathrm{NaCl}$ solution in the absence and in the presence of $5 \mathrm{BID}$ at the optimum concentration $(20 \mathrm{mg} / \mathrm{L})$

\section{Adsorption isotherm}

The adsorption isotherms are considered to describe the interactions between the inhibitor molecule with the active sites on carbon steel. The efficiency of 5BID a successful corrosion inhibitor depends mainly on its adsorption capacity on the metal surface [51]. A plot of $\mathrm{C} / \Theta$ values against the corresponding values of $\mathrm{C}$ was found to be linear for the adsorption of 5BID on carbon steel at different temperatures Figure 7, and for the adsorption of 5BID on carbon steel at $293 \mathrm{~K}$ in Figure 8, which implies that the experimental data are well described by Langmuir isotherm [52].

$$
\begin{aligned}
& \ln \frac{\theta}{1-\theta}=\ln \mathrm{K}+\mathrm{y} \ln \mathrm{C}_{\mathrm{inh}} \\
& \frac{\mathrm{C}}{\theta}=\frac{1}{\mathrm{~K}}+\mathrm{C}
\end{aligned}
$$

Where $\theta$ is the surface coverage degree, $\mathrm{C}$ is the inhibitor concentration in the electrolyte and $\mathrm{K}$ is the equilibrium constant of the adsorption process. The constant of adsorption, Kads, is related to the standard free energy of adsorption $\Delta \mathrm{G}^{\circ}$ ads, with the following equation:

$$
K_{a d s}=\frac{1}{C_{H 2 O}} \exp \left(\frac{-\Delta G_{a d s}^{\circ}}{R T}\right)
$$

Where $\mathrm{R}$ is the universal gas constant, $\mathrm{T}$ the thermodynamic temperature and the concentration of water in the solution is $1000 \mathrm{~g} / \mathrm{l}$. The calculated parameters are reported in the Table 11. Negative values of the $\Delta \mathrm{G}^{\circ}$ ads reflect spontaneous adsorption and strong interaction of inhibitory molecules on the surface of the carbon steel. In general, values of $\Delta \mathrm{G}^{\circ}$ ads around or below $\left(-20 \mathrm{~kJ} \cdot \mathrm{mol}^{-1}\right)$ are compatible with physisorption and those around or more negative than $(-40$ $\mathrm{kJ} . \mathrm{mol}^{-1}$ ) involve chemisorptions [53]. The calculated values for $\Delta \mathrm{G}^{\circ}$ ads have been found in the range of $(-11.62$ to -12.40 $\left.\mathrm{kJ} . \mathrm{mol}^{-1}\right)$ at different temperatures (293-333 K), these values fall between the threshold values for the physisorption. The equation implies the relationship between $\Delta \mathrm{G}^{\circ}$ ads, $\Delta \mathrm{S}^{\circ}$ ads and $\Delta \mathrm{H}^{\circ}$ ads.

$$
\Delta G_{\text {ads }}^{\circ}=\Delta H_{\text {ads }}^{\circ}-T \Delta S_{\text {ads }}^{\circ}
$$

The negative value of $\Delta \mathrm{H}^{\circ}$ ads, reflects the adsorption of inhibitory molecules on the carbon steel surface is an exothermic process and the calculation of the standard enthalpy of adsorption $\Delta \mathrm{H}^{\circ}$ ads obtained by the Van't Hoff equation (Method 2) [54]:

$$
\text { Ln } K_{a d s}=-\Delta H_{\text {ads }}^{\circ} R T+\text { constant. }
$$

Table 11: Langmuir adsorption parameters for the inhibitor adsorption at the optimum concentration

\begin{tabular}{|c|c|c|c|c|c|}
\hline $\mathrm{T}(\mathrm{K})$ & $\begin{array}{c}\mathrm{K}_{\mathrm{ads}} \\
\left(\mathrm{L} \mathrm{mol}^{-1}\right)\end{array}$ & $\begin{array}{c}\Delta \mathrm{G}_{\mathrm{ads}} \\
\left(\mathrm{kJ}^{\mathrm{m}} \mathrm{mol}^{-1}\right)\end{array}$ & $\begin{array}{c}\Delta \mathrm{H}_{\mathrm{ads}} \\
\left(\mathrm{kJ}^{\mathrm{m}} \mathrm{mol}^{-1}\right)\end{array}$ & $\begin{array}{c}\Delta \mathrm{S}_{\mathrm{ads}} \\
\left(\mathrm{kJ} \cdot \mathrm{mol}^{-1} \mathrm{~K}^{-1}\right)\end{array}$ & $\mathrm{R}^{2}$ \\
\hline 293 & $2.51 \times 10^{6}$ & -11.62 & & & 0.9830 \\
\hline 303 & $2.32 \times 10^{6}$ & -11.81 & & & 0.9939 \\
\hline 313 & $2.18 \times 10^{6}$ & -12.01 & \multirow{2}{*}{-5.9164} & \multirow{2}{*}{0.0194825} & 0.9908 \\
\hline 323 & $2.04 \times 10^{6}$ & -12.20 & & & 0.9959 \\
\hline 333 & $1.87 \times 10^{6}$ & -12.40 & & & 0.9940 \\
\hline
\end{tabular}

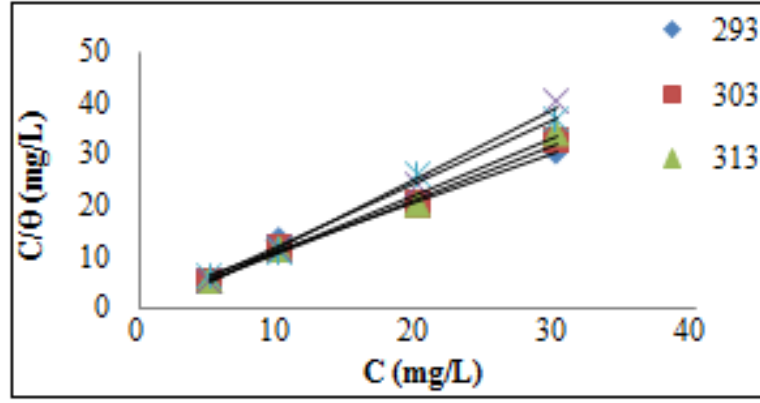

Figure 7: Langmuir isotherms plots for the adsorption of 5BID on carbon steel at different temperatures.

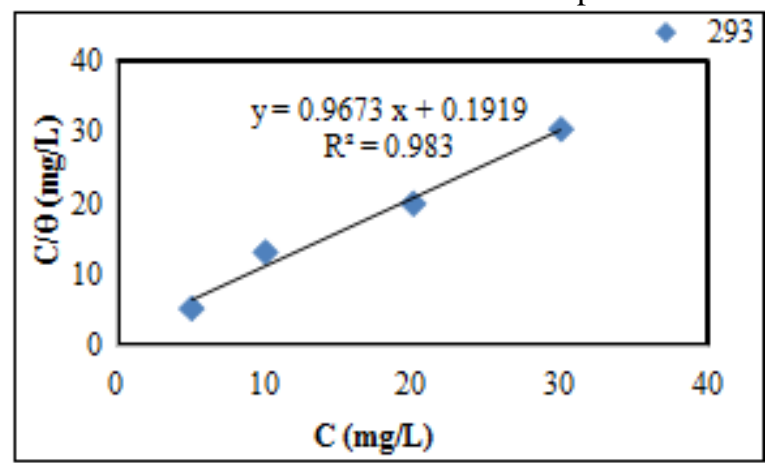

Figure 8: Langmuir isotherms plots for the adsorption of 5BID on carbon steel at $293 \mathrm{~K}$.

\section{Volume 6 Issue 7, July 2017 www.ijsr.net}




\section{International Journal of Science and Research (IJSR) \\ ISSN (Online): 2319-7064 \\ Index Copernicus Value (2015): 78.96 | Impact Factor (2015): 6.391}

Scanning Electron Microscopy (SEM)

In Figure 9a, the badly damaged surface obtained when the metal was kept immersed in a $3.5 \% \mathrm{NaCl}$ solution without inhibitor indicates significant corrosion. However, in the presence of inhibitors Figure $9 \mathrm{~b}$ the surface has remarkably improved with respect to its smoothness as compared to

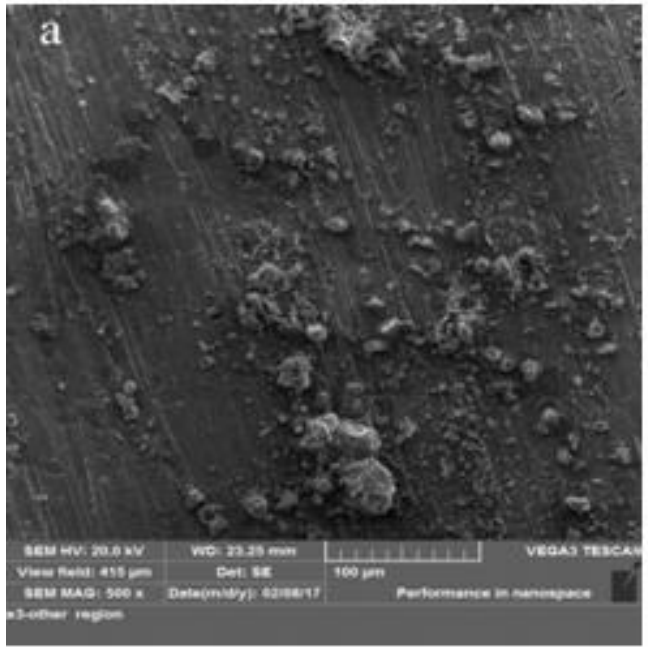

Figure 9a, indicating a considerable reduction of the corrosion rate. This improvement in surface morphology is due to the formation of a protective film of inhibitor on the mild steel surface which is responsible for inhibition of corrosion [55].

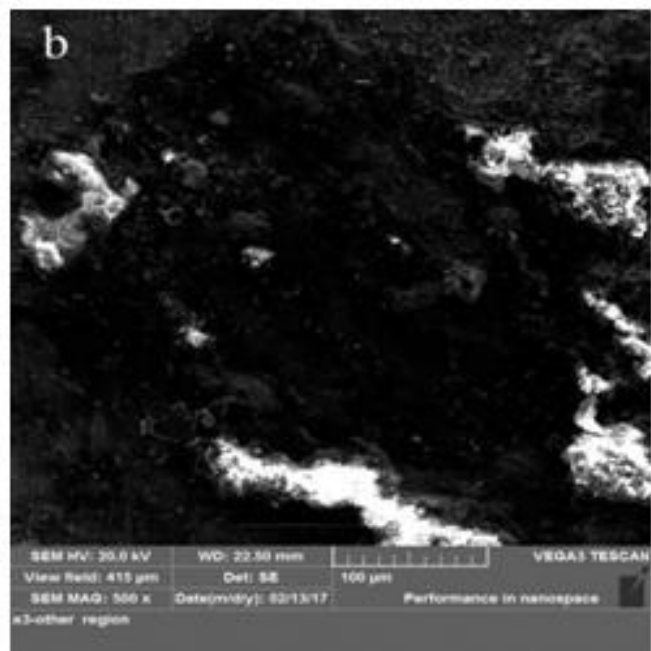

Figure 9: $\mathrm{SEM}$ images of carbon steel in a $3.5 \% \mathrm{NaCl}$ solution immersion at $333 \mathrm{~K}$ (a) after immersion without inhibitor (b) in presence of inhibitor 5BID

\section{Energy dispersive spectroscopy}

The results of EDS spectra are shown in Figure (10 a, b). Figure 10a represents the EDS spectra of abraded and uninhibited carbon steel specimen and Figure 10b depicts inhibited carbon steel specimen. The abraded carbon steel specimen show characteristic peaks for elements (Fe, O, C, $\mathrm{Mn}, \mathrm{Na}, \mathrm{Si}, \mathrm{Cl}$ ) constituting the carbon steel sample. The EDS spectra of the uninhibited carbon steel sample Figure $10 \mathrm{~b}$ show a peak corresponding to $\mathrm{Ti}, \mathrm{Ca}, \mathrm{S}$ in addition to the abraded sample peaks. but show a peak of (Fe, O) in the abraded carbon steel specimen more in addition to the abraded sample the EDS spectra of inhibited carbon steel contains the peaks corresponding to all the elements present in the inhibitor molecules in addition to the uninhibited sample, indicating the adsorption of inhibitor molecules at the surface of carbon steel. In addition to that, EDS of inhibited spectra shows that the Fe peaks are considerably suppressed as compared to the abraded and uninhibited carbon steel sample. The suppression of the Fe lines might be due to an overlying inhibitor film. This indicates that the carbon steel surface was covered with protective film of inhibitor molecules.

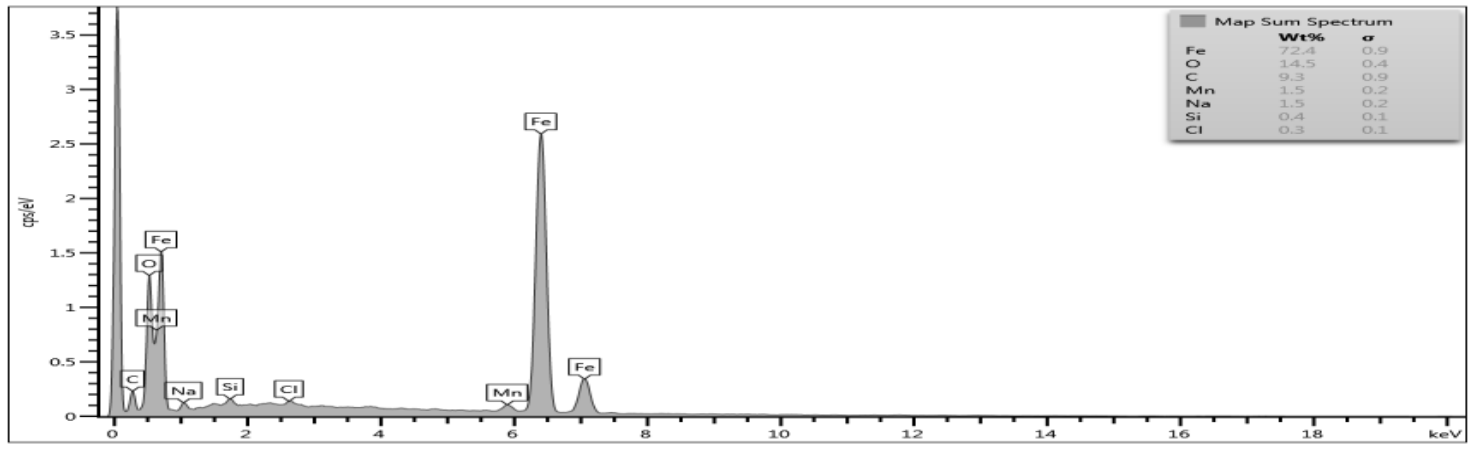

Figure 10: a- EDS spectrum of the surface of $\mathrm{CS}$ in $3.5 \% \mathrm{NaCl}$ in the absence of the inhibitor

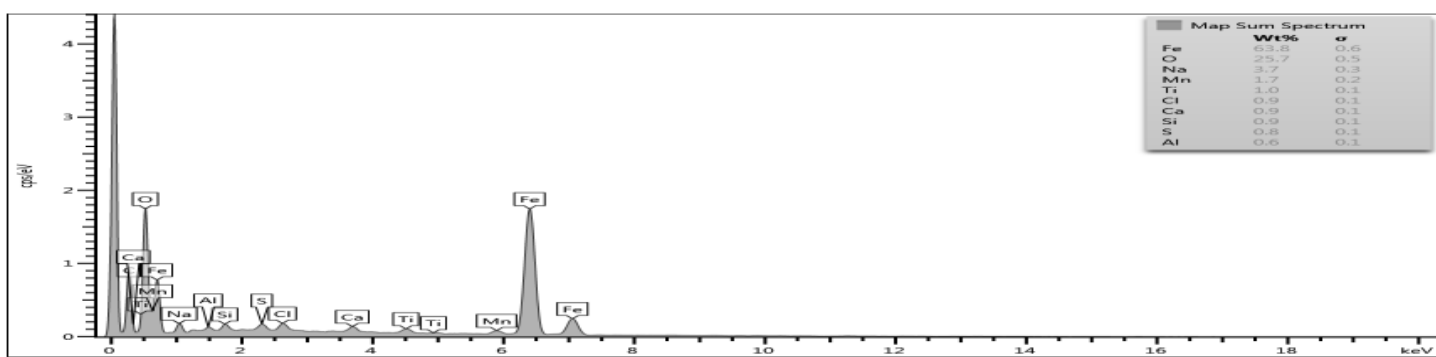

Figure 10: b- EDS spectrum of the surface of $\mathrm{CS}$ in $3.5 \% . \mathrm{NaCl}$ in presence of inhibitor

\section{Atomic force microscopy}

Surface morphology of carbon steel sample in a $3.5 \% \mathrm{NaCl}$

solution in the absence and presence of inhibitors was investigated by atomic force microscopy (AFM). The results are shown in Figure $11(\mathrm{a}-\mathrm{f})$. The average roughness is clearly shown in Figure $11(\mathrm{a}, \mathrm{b}$ and $\mathrm{c})$ that carbon steel

\section{Volume 6 Issue 7, July 2017 www.ijsr.net}




\section{International Journal of Science and Research (IJSR) \\ ISSN (Online): 2319-7064 \\ Index Copernicus Value (2015): 78.96 | Impact Factor (2015): 6.391}

sample is badly damaged due to the $3,5 \% \mathrm{NaCl}$ salt attack on the surface, The $(\mathrm{Sa}),(\mathrm{Sq}),(\mathrm{Sy})$ for the carbon steel surface are $28.2 \mathrm{~nm}, 34.1 \mathrm{~nm}$, and $184 \mathrm{~nm}$, respectively. However, in the presence of an optimum concentration (20ppm) of 5BIO as shown in Figure 11(d, e and f) the average roughness was reduced. that display the steel surface after immersion in $3.5 \% \mathrm{NaCl}$ presence of inhibitor. The $(\mathrm{Sa}),(\mathrm{Sq}),(\mathrm{Sy})$ for the carbon steel surface are $15.1 \mathrm{~nm}, 17.6 \mathrm{~nm}$, and $86.3 \mathrm{~nm}$, respectively [56].
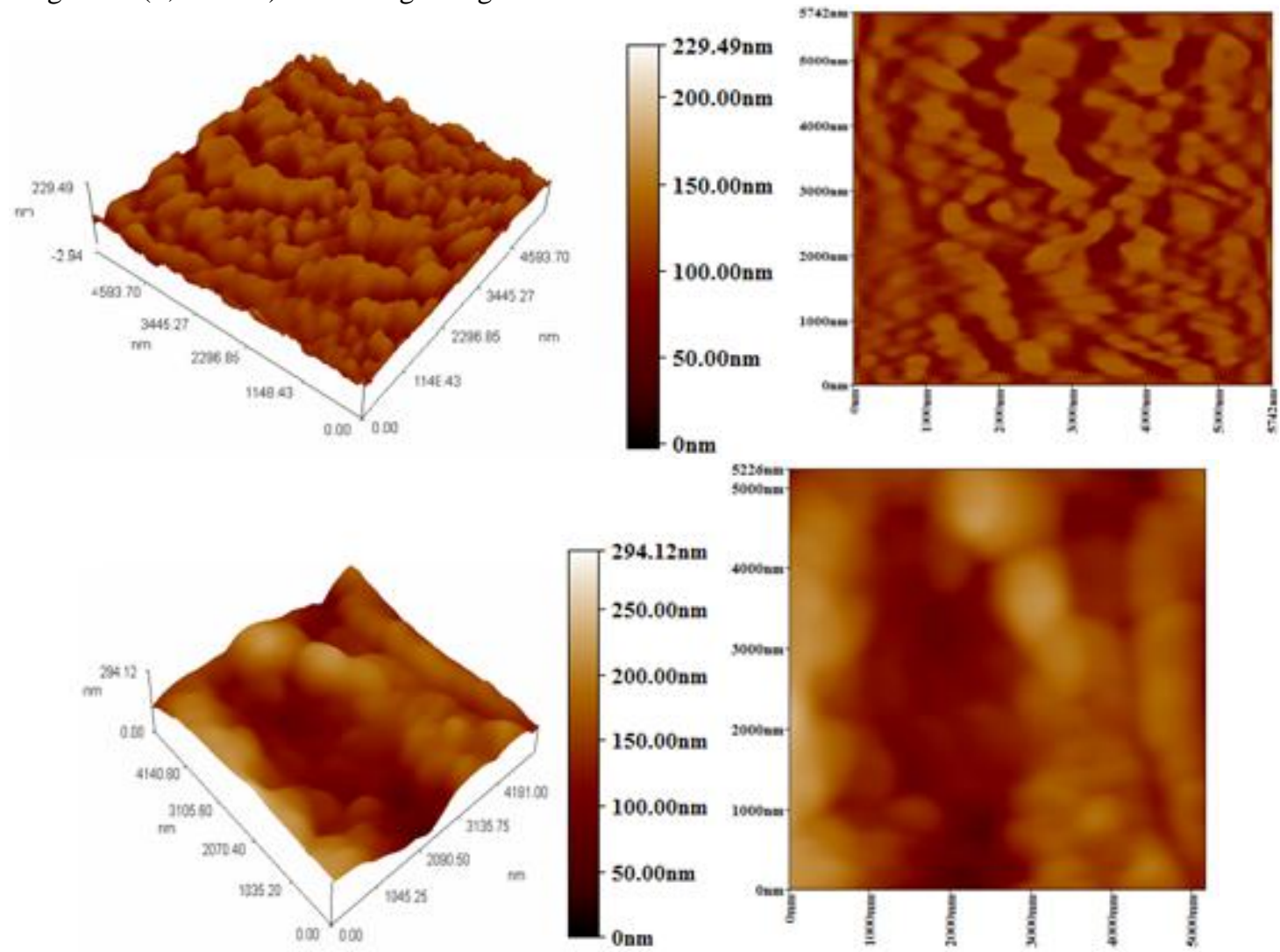

Figure 11: AFM micrograph of carbon steel surface $(\mathrm{a}, \mathrm{b}, \mathrm{c})$ in a 3,5\% $\mathrm{NaCl}$ solution, $(\mathrm{d}, \mathrm{e}, \mathrm{f})$ in presence of $20 \mathrm{ppm} 5 \mathrm{BIO}$

\section{References}

[1] C.A.C. Sequeira, Corrosion of copper and copper alloys, in Uhlig's Corrosion Handbook, 2nd edition, R. W. Revie, editor, Wiley, New York, (2000) p. 755

[2] P. Agarwal, D. Landolt, Corrosion Science, 260 (1998), 673-691

[3] C. Liang, J. Xia, D. Lei, X. Li, Q. Yao and J. Gao. Synthesis, in vitro and in vivo antitumor activity of symmetrical bis-Schiff base derivatives of isatin, Eur $\mathbf{J}$. Med Chem, 74 (2013) 742-750.

[4] A. Zarrouk, B. Hammouti, A. Dafali and F. Bentiss Inhibitive properties and adsorption of purpald as a corrosion inhibitor for copper in nitric acid medium, Ind. Eng. Chem. Res., 52, (2013) 2560-2568.

[5] H. Zarrok, H. Oudda, A. El Midaoui, A. Zarrouk, B. Hammouti, M. Ebn Touhami, A. Attayibat, S. Radi and R. Touzani, Res. Chem. Intermed. 38 (2012) 2051.

[6] W.C. Sumpter, The chemistry of isatin. Chem. Rev., 34(3), (1944) 393-434.

[7] F. Joaquim, M. da Silva, S.J. Garden and A. C. Pinto, The Chemistry of Isatins: a Review from 1975 to 1999J. Braz. Chem. Soc., J. Braz. Chem. Soc.,12(3), (2001) 273-324.

[8] J. Azizian, M.K. Mohammadi, O. Firuzi, N. Razzaghiasl and M.R. Nima, Synthesis, biological activity and docking study of some new isatin Schiff base derivatives, Med. Chem. Research, 21(11), (2012) 3730-3740.

[9] F.D. Popp, R. Parson and B.E. Donigan, The condensation of isatin with cyclic ketones, J. Heterocyclic Chem., 17, (1980) 1329-1330.

[10] J. Bergman, Jan-Olof Lindstrom and ULF Tilstam, Tetrahedron, 41(14), (1985) 2879-2881.

[11] L.Wei, Q.Wang, X .Liu and Y. F. Zazhi, Yaowu Fenxi Zazhi 2(288), (1982), (CA 98:95726b).

[12] M. Ischia, M.A. Palum and G. Prota. Adrenalin oxidation revisited. New products beyond the adrenochrome stage, Tetrahedron. 44, (1988) 64416446.

[13] S. Datta, S.C. Datta, J. Chromatogr., 170, 228, 1979.

[14] Presentation Prepared by Dr. Niels Lindquist, University of North Carolina at Chapel Hill.

[15] G.J. Kapadia, Y.N. Shukla, B.K. Chowdhury, J. Chem. Soc., Chem. Commun. (1977) 535.

[16] I.B. Obot, N.O. Obi-Egbedi, A.O. Eseola, Anticorrosion potential of 2-Mesityl-1H-imidazo[4,5f] $[1,10]$ phenanthroline on mild steel in sulfuric acid solution: Experimental and theoretical study. Ind. Eng. Chem. Res., 50(4), (2011) 2098-2110.

[17] R.M. Kubba and M.M. Khathem. Theoretical studies of corrosion inhibition efficiency of two new N-phenylethylidene-5-bromo isatin derivatives. Iraqi Journal of Science. 57(2B), (2016) 1041-1051.

[18] R.M. Kubba and M.M. Khathem. PM3 and DFT quantum mechanical calculations of two new $\mathrm{N}$ -

\section{Volume 6 Issue 7, July 2017 www.ijsr.net}




\section{International Journal of Science and Research (IJSR) \\ ISSN (Online): 2319-7064}

Index Copernicus Value (2015): 78.96 | Impact Factor (2015): 6.391

benzyl-5-bromo isatin derivatives as corrosion inhibitors. Iraqi Journal of Science, 5(8), (2016) 16-26.

[19] H.J. Ahmed, Synthesis, characterization and study of antimicrobial activity of some new Schiff base derivatives containing 5-bromo isatin moiety. M.Sc. 2015. Thesis. Department of Chemistry, College of Science, University of Baghdad. Baghdad, Iraq.

[20] S.M.H. Al-Majidi and K.T.A. Al-Sultani ,.AlMustansiriya, J. Scie. 21(4), (2010) 61-72.

[21] S.M.H Al-Majidi, M. Rafat. and A. Karim. Synthesis and characterization of novel 1,8-Naphthalimide derivatives containing 1,3-oxazoles, 1,3-thiazoles, 1,2,4-triazoles as antimicrobial agents, J. Al-Nahrain University, 16(4), (2013) 55-66.

[22] S.M.H. Al-Majidi and W.W.N. Al-Kaisy, Proceeding of 3rd scientific conference: (2009).

[23] I.B. Obot, and N.O. Obi-Egbedi. 2, 3Diphenylbenzoquinoxaline: A new corrosion inhibitor for mild steel in sulphuric acid. Corros. Sci., 52(1), (2010). 282-285.

[24] S.A. Umoren, I.B. Obot, E.E. Ebenso and N.O. ObiEgbedi. Synergistic inhibition between naturally occurring exudate gum and halide ions on the corrosion of mild steel in acidic medium Int. J. Electrochem. Sci., 3, (2008) 1029-1043.

[25] M.J. Frisch, G.W. Trucks, H.B. Schlegel, G.E. Scuseria, M.A. Robb, J.R. Cheeseman, J.A. Montgomery, J.A. Jr., Vreven, T. Kudin, K.N. Burant, J.C. Millam, J.M. Iyengar, S.S. Tomasi, J. Barone, V. Mennucci, B. Cossi, M. Scalmani, G. Rega, N. Petersson, G.A. Nakatsuji, H. Hada, M. Ehara, M. Toyota, K. Fukuda, R. Hasegawa, J. Ishida, M. Nakajima, T. Honda, Y. Kitao, O. Nakai, H. Klene, M. Li, X. Knox, J.E. Hratchian, H.P. Cross, J.B. Bakken, V. Adamo, C. Jaramillo,J. Gomperts, R. Stratmann,R. E. Yazyev, O.Austin, A.J. Cammi,R. Pomelli,C Ochterski, J.W. Ayala, P.Y. Morokuma, K. Voth, G.A. Salvador, P. Dannenberg, J.J. Zakrzewski, V.G. Dapprich, S. Daniels, A.D. Strain, M.C. Farkas, O. Malick, D.K. Rabuck, A. D. Raghavachari, K Foresman, J. B. Ortiz,J. V Cui, Q. Baboul, A. G. Clifford, S. Cioslowski, J. Stefanov, B.B. Liu, G. Liashenko, A. Piskorz, P. Komaromi, I. Martin, R.L. Fox, D.J. Keith, T. Al-Laham, M.A. Peng, C.Y. Nanayakkara, A. Challacombe, M. Gill, P.M. W. Johnson B. Chen, W. Wong, M.W. Gonzalez, C. and Pople, J.A. 2009. Gaussian. Inc. Pittsburgh PA.

[26] A.D. Becke. Density-functional thermochemistry. III. The role of exact exchange, J. Chem. Phys., 98 (1993) 5648-5652.

[27] C. Ee, W. Yang and R.G. Parr. Development of the Colle-Salvetti correlation-energy formula into a functional of the electron density, Phys. Rev., B41 (1988) 785-789.

[28] R.G. Parr and W. Yang. Density functional approach to the frontier-electron theory of chemical reactivity, Chem. Phys., 106, (1984) 4049-4050.

[29] Kubba, R.M. and Abood, F.K. Quantum chemical investigation of some schiff bases as corrosion inhibitors for mild steel in hydrochloric acid solutions. Iraqi Journal of Science,56(2B), (2015) 1241-1257.

[30] Kubba, R.M. and Abood, F.K. DFT, PM3, AM1, and MINDO/3 Quantum Mechanical Calculations for Some
INHC Cs Symmetry Schiff Bases as Corrosion Inhibitors for Mild Steel. Iraqi Journal of Science,56(2B), (2015) 602-126

[31] R.M. Kubba and A.S. Alag. Experimental and theoretical evaluation of new quinazolinone derivative as organic corrosion inhibitor for carbon steel in $1 \mathrm{M}$ $\mathrm{HCl}$ solution. International Journal of Science and Research (IJSR) (6), (2017) 1832-1643.

[32] Gokhan Gece, Corros. Sci., 50, (2008) 2981-2992.

[33] El Sayed H. El-Ashry, A. El-Nemr, S.A. Esawy and S. Ragab, Electrochim. Acta., 51, (2006) 3957-3968.

[34] N.O. Eddy, B.I. Ita and E. E. Ebenso Experimental and Theoretical studies on the Corrosion Inhibition potentials of some anisole derivatives for mild steel. Inter. J. Electrochem. Sci., 6; (2011) 2101-2121

[35] M. Lebrini, M. Lagrenee, M. Traisnel, L. Gengembre, H. Vezin and F. Bentiss, Appl. Surf. Sci., 253, (2007) 9267-9276.

[36] V.S. Sastri and J.R. Perumareddi, Corrosion, 53(8), (1997) 617-622.

[37] R.G. Pearson, Inorg. Chem., 27, (1988) 734-740.

[38] S. Martinez, Mater. Chem. Phys., 77, (2002), 97-102.

[39] I. Lukovits, E. Kalman and F. Zucchi. Corrosion inhibitors correlation between electronic structure and efficiency, CORROSION, 57(1), (2001) 3-8.

[40] A. Stoyanova, G. Petkova, and S.D. Peyerimhoff. Correlation between the molecular structure and the corrosion inhibiting effect of some pyrophtalone compounds. Chem. Phys., 279, (2002) 1-6.

[41] X. Li, S. Deng, H. Fu and T. Li. Adsorption and inhibition effect of 6-benzyl aminopurine on cold rolled steel in 1.0 M HCl, Electrochimica Acta., 54(16), (2009) 4089-4098.

[42] M. Herbert, S. Jacob, N. Howard and J. George, "Organic chemistry Schaum's outlines", 4th edition. McGraw-Hill Companies, Inc. USA, 2010.

[43] N.S. Isaacs. Synthetic routes to $\beta$ lactams. Chem. Soc. Rev., 5 (1976) 181-202.

[44] J. March. "Advanced Organic Chemistry" 3rd edition, Wiley, New York, USA, 1985.

[45] A.I. Vogel, (Textbook of practical organic chemistry) 5th Edition, Longman, 1996.

[46] D. Ben Hmamou, M.R. Aouad, R. Salghi, A. Zarrouk, M. Assouag, O. Benali, M. Messali, H. Zarrok and B. Hammouti, Inhibition of C38 steel corrosion in hydrochloric a cid solution by 4,5-Diphenyl-1HImidazole-2-Thiol:Gravimetric and temperature effects treatments, J. Chem. Pharm. Res., 4(7), (2012) 34983504

[47] S. Hong, W. Chen, H.Q. Luo and N.B. Li. Inhibition effect of 4-amino-antipyrine on the corrosion of copper in 3 wt.\% $\mathrm{NaCl}$ solution. Corr. Sci., 57 (2012) 270278.

[48] S. V. Ramesh, V. Adhikari, Bull. Mater. Sci. 31 (2007) 699.

[49] M. Behpour, S. M. Ghoreishi, N. Soltani, M. SalavatiNiasari, M. Hamadanian, A. Gandomi, Corros. Sci. 50 (2008) 2172-2181.

[50] X. Wang, H. Yang, F. Wang, Corros. Sci. 53 (2011) 113.

[51] [51] M. Tourabi, K. Nohair, A. Nyassi, B. Hammouti, C. Jama and F. Bentiss., J. Mater. Thermodynamic characterization of metal dissolution and inhibitor

\section{Volume 6 Issue 7, July 2017 www.ijsr.net}




\section{International Journal of Science and Research (IJSR) \\ ISSN (Online): 2319-7064}

Index Copernicus Value (2015): 78.96 | Impact Factor (2015): 6.391

adsorption processes in mild steel / 3,5-bis(3,4dimethoxyphenyl)-4-amino-1,2,4-triazole hydrochloric acid system Environ. Sci. 5 (4) (2014) 1133-1143.

[52] [52] M. Outirite, M. Lagrenée, M. Lebrini M. Traisnel, C. Jama, H. Vezin and F. Bentiss. Ac impedance, X-ray photoelectron spectroscopy and density functional theory studies of 3,5-bis(n-pyridyl)-1,2,4-oxadiazoles as efficient corrosion inhibitors for carbon steel surface in hydrochloric acid solution., Electrochim. Acta., 55 (2010) 1670-1681.

[53] [53] A. Zarrouk, B. Hammouti, T. Lakhlifi, M. Traisnel, H. Vezin and F. Bentiss, Corros. Sci. 90 (2015) 572-584

[54] [54] Bouklah M., Hammouti B., Lagrenée M., Bentiss F., Corros. Sci. 48 (2006) 2831.

[55] [55] A. Mohamed, K. Abbas, A. Zakaria, O.M. Hamdy, E. Abo and E. Olfat. Synthesis of Novel Schiff Base Silicon Compound for Employing as Corrosion Inhibitor for Carbon Steel in the 1M HCL and 3.5\% $\mathrm{NaCl}$ Aqueous Media., Inter. J. Chem., 3 (2015) 23204087.

[56] [56] B.S. Devi and S. Rajendran. Influence of garlic extract on the inhibition efficiency of tri sodium citrate., Inter. J. Chem. Sci. Tech., 1, (2011) 79-87.

Volume 6 Issue 7, July 2017 www.ijsr.net 